\title{
CARDIAC GLYCOSIDE RECEPTORS IN CULTURED HEART CELLS-I. CHARACTERIZATION OF ONE SINGLE CLASS OF HIGH AFFINITY RECEPTORS IN HEART MUSCLE CELLS FROM CHICK EMBRYOS
}

\author{
Karl Werdan, Bernhard Wagenknecht, Bernhard Zwissler, Lindsay Brown, \\ WOLFGANG KRAWIETZ and ERLAND ERDMANN \\ Medizinische Klinik I der Universität München, Klinikum Großhadern, D-8000 München 70, F.R.G.
}

(Received 15 April 1983; accepted 13 July 1983)

\begin{abstract}
Binding of $\left({ }^{3} \mathrm{H}\right)$-ouabain and ouabain-induced inhibition of the sodium pump and of the $\left(\mathrm{Na}^{+}+\mathrm{K}^{+}\right)$-ATPase have been characterized in cultured cardiac muscle and non muscle cells, as well as in cardiac cell membranes-all obtained from chick embryos.

1. In both cell types, ouabain binds to a single type of binding sites in a temperature-dependent manner. The association rate but not the dissociation rate, is lowered by $\mathrm{K}^{+}$; specific binding is lost after heat-denaturation of the cells. Binding parameters (association and dissociation rate constants, activation energies for association and dissociation) are similar in muscle and non muscle cells. The dissociation constant of specific ouabain binding is $1.5 \times 10^{-7} \mathrm{M}$ in cardiac muscle cells, and $1.9 \times 10^{-7} \mathrm{M}$ in cardiac non muscle cells, the binding capacity being 2.6 and $2.1 \mathrm{pmoles} / \mathrm{mg}$ protein respectively.

2. Specific binding of ouabain to the cells is coupled to inhibition of the sodium pump, as can be seen from ouabain-induced inhibition of active $\left({ }^{86} \mathrm{Rb}^{+}+\mathrm{K}^{+}\right)$-uptake, decrease in cellular $\mathrm{K}^{+}$, and increase in cellular $\mathrm{Na}^{+}\left(\mathrm{EC}_{50}=10^{-7}-10^{-6} \mathrm{M}\right)$.

3. The data obtained with cardiac cells are in good agreement with results found for ouabain binding (dissociation constant $\left.4.3 \times 10^{-7} \mathrm{M}\right)$ and $\left(\mathrm{Na}^{+}+\mathrm{K}^{+}\right)$-ATPase inhibition $\left(\mathrm{EC}_{50}=1.4 \times 10^{-6} \mathrm{M}\right)$ in cardiac cell membranes prepared from the same tissue.

4. Due to the experimental evidence it is concluded that the binding site for ouabain is identical with the cardiac glycoside receptor of these cells.

5. In cardiac non muscle cells, binding of ouabain to its receptor is strictly coupled to inhibition of active $\mathrm{K}^{+}$-transport in a stoichiometric manner. In cardiac muscle cells, however, active $\mathrm{K}^{+}$-transport is inhibited by less than $10 \%$ when up to $40 \%$ of cardiac glycoside receptors have bound ouabain. It is assumed that this non-stoichiometric coupling of receptor occupancy and sodium pump inhibition in cardiac muscle cells may prevent substantial changes of $\mathrm{Na}^{+}$- and $\mathrm{K}^{+}$-contents in the heart in the presence of therapeutic levels of cardiac glycosides.
\end{abstract}

The first step in the positive inotropic action of cardiac glycosides is binding of the drug to its receptor, located on the outer surface of the cell membrane. This receptor is part of the $\left(\mathrm{Na}^{+}+\mathrm{K}^{+}\right)$ATPase, the biochemical equivalent of the sodium pump (for review see [13]). Though the sodium pump apparently represents the receptor, the involvement of the well-established glycoside-induced inhibition of the sodium pump in positive inotropic action of this drug is still an open question [27]. Further clarification of this problem requires both: characterization of the receptor, as well as quantitative description of the relationship between receptor occupation by cardiac glycosides, inhibition of the sodium pump and positive inotropic effect in the intact cardiac muscle cell.

Properties of the cardiac glycoside receptor have been thoroughly studied in $\left(\mathrm{Na}^{+}+\mathrm{K}^{+}\right)$-ATPase enriched membrane preparations of cardiac tissues. However, in these studies, a certain disadvantage has to be taken into account: receptor-binding can only be correlated with inhibition of the ATP-splitting activity of $\left(\mathrm{Na}^{+}+\mathrm{K}^{+}\right)$-ATPase, but not with

Part of the results have been presented as a preliminary communication [40] in this journal. inhibition of active $\mathrm{Na}^{+}, \mathrm{K}^{+}$-transport, the physiological function of the enzyme. Therefore, quantitative correlation of cardiac glycoside receptor binding and drug-induced inhibition of the sodium pump can only be investigated in the intact cell.

In this respect, beating myocardial muscle cells in monolayer culture represent a suitable model for studying cardiac glycoside action at the molecular level, because:

1. the cells are sensitive to the drug and respond with an increase in amplitude and velocity of contraction (for review see [33]), representing inotropic effects [19]; active transport of $\mathrm{K}^{+}$and $\mathrm{Na}^{+}$is inhibited by cardiac glycosides in a concentration dependent manner $[6,24]$.

2 . working with monolayer cell cultures avoids difficulties complicating the interpretation of results obtained with cardiac tissue preparations, the latter having a large intercellular space, being composed of muscle as well as non muscle cells (mainly fibroblasts and endothelial cells), and being sensitive to neuronal influence due to the presence of nerve fibres in heart tissue. In heart cells in culture, nerve fibres are absent, the intercellular space is small, and muscle and non muscle cells can be cultured and studied separately. 
3. as the cardiac glycoside receptor is located on the outer surface of the cell membrane [13], it should be easily accessible in intact cells for radioactively labeled ligands, e.g. $\left({ }^{3} \mathrm{H}\right)$-ouabain; therefore, characterization of cardiac glycoside binding to its receptor should be possible in its "natural surroundings".

For these reasons, we have studied binding of $\left({ }^{3} \mathrm{H}\right)$-ouabain to cardiac muscle and non muscle cells in culture, obtained from 10 to 12-day-old chick embryos. In this way, binding could be characterized as receptor-mediated, and the consequences of receptor occupation by its ligand on active $\mathrm{Na}^{+}$, $\mathrm{K}^{+}$-transport could be described in a quantitative manner.

\section{MATERIALS AND METHODS}

Materials. Chemicals were purchased from Biochrom, D1000 Berlin, F.R.G. (Collagenase "Worthington" 125-250 U/mg, CLS II; fetal calf serum; horse serum; CMRL 1415 ATM-medium); Serva Biochemica, D-6900 Heidelberg, F.R.G. (Trypsin $1: 250$, No 37290); NEN Chemicals, D-6072 Dreieich, F.R.G. $\quad\left({ }^{22} \mathrm{NaCl}\right.$ ， carrier-free; ${ }^{86} \mathrm{RbCl}, \quad 0.9-4.6$ $\mathrm{mCi} / \mathrm{mg}$; $\left({ }^{3} \mathrm{H}\right)$-ouabain, $\left.14-20 \mathrm{Ci} / \mathrm{mmol}\right)$. All other chemicals were of analytical grade and purchased from Merck, D-6100 Darmstadt, F.R.G., and Boehringer-Mannheim, D-6800 Mannheim, F.R.G.

Cell culture techniques. Muscle and non muscle cells from hearts of 10-12-day-old chick embryos have been prepared under sterile conditions and separately cultured as described in detail for rat heart cells $[37,38]$. In brief, the procedures are: disaggregation of 50-200 hearts by repeated incubation $\left(10\right.$ min periods at $\left.37^{\circ}\right)$ in trypsin $(0.12 \%)$-collagenase $(0.03 \%)$-salt solution $\left(\mathrm{Ca}^{2+}, \mathrm{Mg}^{2+}\right.$ free); separate cultivation of muscle cells (seeding density $10^{5}$ cells $/ \mathrm{cm}^{2}$ ) and non muscle cells in $25 \mathrm{~cm}^{2}$ plastic flasks (Nunclon Plastics, DK-Roskilde, Denmark) at $37^{\circ}$ after application of the differential attachment technique, in growth medium (CMRL 1415 ATM, bicarbonate-free, supplemented with $10 \%$ fetal calf serum and $0.05 \mathrm{mg} / \mathrm{ml}$ gentamycin, $\mathrm{pH} 7.40$ ). The medium for cultivation of cardiac muscle cells was additionally supplemented with $10 \%$ horse serum. Experiments have been carried out with muscle cells after $2-3$ days in culture, with non muscle cells after one subcultivation (splitting ratio $1: 2$, detachment of the cells by $0.05 \%$ trypsin $+0.02 \%$ EDTA in $\mathrm{Ca}^{2+}, \mathrm{Mg}^{2+}$ free salt solution (Biochrom, Berlin). At that time, muscle cells had formed a synchronously beating monolayer, non muscle cells were at confluency.

The term "non muscle cells" refers to heart cells in culture lacking sarcomeres, mainly consisting of fibroblasts and endothelial cells [23]. In contrast to cardiac muscle cells, they possess a high proliferation capacity and rapidly attach to the culture flask after seeding [7].

Measurement of $\left({ }^{3} \mathrm{H}\right)$-ouabain binding, $\left({ }^{86} \mathrm{Rb}^{+}+\right.$ $\mathrm{K}^{+}$)-influx and cellular contents of $\mathrm{Na}^{+}$and $\mathrm{K}^{+}$in heart cells. Standard measurements have been carried out at $37^{\circ}$ with cells $(0.2-2.0 \mathrm{mg}$ protein/flask $)$ in $25 \mathrm{~cm}^{2}$ plastic flasks in serum-supplemented $(2.5 \%$ fetal calf serum, $2.5 \%$ horse serum), Hepes buffered (20 mM, pH 7.40) CMRL 1415 ATM medium with lowered $\mathrm{K}^{+}$concentration $(0.75 \mathrm{mM})$ (= standard medium). For measurement of $\left({ }^{86} \mathrm{Rb}^{+}+\mathrm{K}^{+}\right)$-uptake rates, cells have been incubated for $10 \mathrm{~min}$ with $\left({ }^{86} \mathrm{Rb}^{+}\right)$in tracer amounts. Washing procedures, lysis of the cells, determination of cellular radioactivity and measurement of cellular protein according to the method of Lowry-using bovine serum albumin as standard-have been described in detail elsewhere [37]. Measurement of $\left({ }^{3} \mathrm{H}\right)$-ouabain binding to the cells has been carried out in a similar manner (see also legends to figures and tables). Cellular $\mathrm{K}^{+}$contents have been measured by flame photometry, the exchangeable pool of intracellular $\mathrm{Na}^{+}$has been obtained by measurement of cellular ${ }^{22} \mathrm{Na}^{+}$tracer under equilibrium conditions [38].

Preparation of $\left(\mathrm{Na}^{+}+\mathrm{K}^{+}\right)$-ATPase enriched cardiac cell membranes from chick embryos. The hearts of 300 chicken embryos (13-day-old, $12 \mathrm{~g}$ wet wt) were homogenized in $60 \mathrm{ml} 0.25 \mathrm{M}$ sucrose- $1 \mathrm{mM}$ EDTA-solution, $\mathrm{pH} 7.25$. After centrifugation at $15,000 \mathrm{rpm}$ for $30 \mathrm{~min}$ (Beckman L-5-50. Ti60 rotor), the pellet was suspended in $60 \mathrm{ml}$ sucrose-EDTA buffer. $\mathrm{NaI}(6 \mathrm{M}, 15 \mathrm{ml})$ was added dropwise. After stirring for $5 \mathrm{~min}, 120 \mathrm{ml}$ of $1 \mathrm{mM}$ EDTA, pH 7.25. were added, and the suspension was centrifuged at $35,000 \mathrm{rpm}$ for $30 \mathrm{~min}$ (Ti60 rotor). The pellet was washed four times by suspending in $200 \mathrm{ml}$ EDTA solution ( $1 \mathrm{mM}, \mathrm{pH} 7.25)$ and centrifuging at $35,000 \mathrm{rpm}$ for $30 \mathrm{~min}$ (Ti 60 rotor) each. The final pellet was suspended in $100 \mathrm{ml}$ EDTA solution (1 mM, pH 7.25).

$\left(\mathrm{Na}^{+}+\mathrm{K}^{+}\right)$-ATPase activity was measured by the coupled optical assay [34]. $\left(\mathrm{Na}^{+}+\mathrm{K}^{+}\right)$-ATPase activity was about $0.16 \mu$ moles ATP hydrolyzed per min per mg protein at $37^{\circ}$. About $75 \%$ of this activity was inhibited by $1 \times 10^{-3} \mathrm{M}$ ouabain. Protein was measured by the procedure of Lowry et al, using bovine serum albumin as standard.

Measurement of $\left({ }^{3} \mathrm{H}\right)$-ouabain binding and $\left(\mathrm{Na}^{+}+\mathrm{K}^{+}\right)$-ATPase activity in cardiac cell membranes from chick embryos. Cardiac cell membranes were incubated at $37^{\circ}$ with $3 \mathrm{mM} \mathrm{MgCl}, 3 \mathrm{mM}$ imidazole $/ \mathrm{PO}_{4}, 2.8 \mathrm{nM}\left({ }^{3} \mathrm{H}\right)$-ouabain and increasing concentrations of unlabelled ouabain $\left(1 \times 10^{-7}\right.$ to $\left.1 \times 10^{-3} \mathrm{M}\right)$ in $50 \mathrm{mM}$ imidazole/ $\mathrm{HCl} \mathrm{pH} \mathrm{7.25,} \mathrm{final}$ volume $2.0 \mathrm{ml}$. After an incubation period of $2 \mathrm{hr}$-representing equilibrium conditions for binding $-0.4 \mathrm{ml}$ of this incubation mixture was taken for determination of $\left(\mathrm{Na}^{+}+\mathrm{K}^{+}\right)$-ATPase activity (coupled optical assay), and the remaining $1.6 \mathrm{ml}$ was used for determination of $\left({ }^{3} \mathrm{H}\right)$-ouabain binding (rapid filtration method according to ref. [12]). In the coupled optical assay [NADH] decrease was linear during the duration of the assay. The same concentration of unlabelled ouabain as in each incubation mixture was added to each cuvette.

Association and dissociation rate constants were measured and calculated as described previously [11].

Estimation of cardiac glycoside receptor density and sodium pump turnover rate in cardiac muscle and non muscle cells from chick embryos. Receptor density can be estimated using the following data for heart muscle cells: 2.6 pmoles $\left({ }^{3} \mathrm{H}\right)$ ouabain bound $/ \mathrm{mg}$ protein (Table 3 ) $; 0.55 \mathrm{mg}$ cell protein $/ 10^{6}$ cells [40]; about $2000 \mu \mathrm{m}^{2}$ cell surface/cell [24]. For heart non muscle cells, the corresponding data are: 
$2.1 \mathrm{pmoles} / \mathrm{mg}$ protein [Table 3]; $0.24 \mathrm{mg}$ cell protein $/ 10^{6}$ cells [40]; about $1000 \mu \mathrm{m}^{2}$ cell surface/cell [8]. For estimation of sodium pump turnover rate, active $\left({ }^{86} \mathrm{Rb}^{+}+\mathrm{K}^{+}\right)$-influx/mg protein is divided by the amount of $\left({ }^{3} \mathrm{H}\right)$-ouabain bound per mg cell protein (Table 3). The rate of active $\left({ }^{86} \mathrm{Rb}^{+}+\mathrm{K}^{+}\right)$-influx under the experimental conditions used $\left(\left[\mathrm{K}^{+}\right]=\right.$ $0.75 \mathrm{mM}$ ) is calculated as $0.26 \mathrm{nmoles} / \mathrm{mg}$ protein $\times$ s (heart muscle cells) and 0.13 (heart non muscle cells) resp. [40]. The estimation is based on the assumption that (a) $\left({ }^{86} \mathrm{Rb}^{+}\right)$-ions are taken up into the cells with similar transport velocity as $\mathrm{K}^{+}$-ions $[37,38]$; (b) each sodium pump molecule binds one ouabain molecule; (c) two $\mathrm{K}^{+}$-ions are taken up per pump event.

The data presented in this report are mean values from closely correlating duplicates or triplicates. If not stated otherwise, all experiments have been carried out at least three times. Representative standard deviation values have been given in some of the experiments.

\section{RESULTS}

$\left({ }^{3} \mathrm{H}\right)$-Ouabain binding and $\left(\mathrm{Na}^{+}+\mathrm{K}^{+}\right)$-ATPase inhibition in cardiac cell membranes from chick embryos. For reasons of comparison, $\left({ }^{3} \mathrm{H}\right)$-ouabain binding and $\left(\mathrm{Na}^{+}+\mathrm{K}^{+}\right)$-ATPase inhibition have not only been studied in intact myocardial cells in culture (see next paragraphs), but also in $\left(\mathrm{Na}^{+}+\mathrm{K}^{+}\right.$) ATPase enriched cardiac membranes obtained from hearts of chick embryos, the same source as used for preparation of heart cells.

For measurement of $\left({ }^{3} \mathrm{H}\right)$-ouabain binding and enzyme inhibition under identical conditions, cardiac membranes have been incubated with $\left({ }^{3} \mathrm{H}\right)$-ouabain $\left(10^{-7}-10^{-3} \mathrm{M}\right)$. After an incubation period of $2 \mathrm{hr}$-representing equilibrium conditions for binding - $\left({ }^{3} \mathrm{H}\right)$-ouabain binding has been determined by rapid filtration method $(\mathrm{O}-\mathrm{O})$, and $\left(\mathrm{Na}^{+}+\mathrm{K}^{+}\right)$-ATPase activity $(-)$) has been measured by the coupled optical assay (Fig. 1a). Plotting the binding data according to Scatchard [32], a straight line is obtained, representing one single class of ouabain binding sites (Fig. 1b). From the slope of the line, a dissociation constant $\left(K_{\mathrm{D}}\right)$ of $4.3 \times 10^{-7} \mathrm{M}$ can be obtained.

For inhibition of $\left(\mathrm{Na}^{+}+\mathrm{K}^{+}\right)$-ATPase activity, a $\mathrm{EC}_{50}$ of $1.4 \times 10^{-6} \mathrm{M}$ is found, which agrees well with the value $\left(2.7 \times 10^{-6} \mathrm{M}\right)$ reported by Sperelakis and Lee [36].

Ligand binding site interaction is further characterized in the experiments of Fig. 2: the association process of specific $\left({ }^{3} \mathrm{H}\right)$-ouabain binding follows second order kinetics (Fig. 2a, $\mathrm{O}-\mathrm{O}$ ). while dissociation of $\left({ }^{3} \mathrm{H}\right)$-ouabain is a strictly first order process (Fig. 2b, $\mathrm{O}-\mathrm{O}$ ). From the ratio of the dissociation rate constant $k_{-1}$ and the association rate constant $k_{+1}$, the dissociation constant $K_{\mathrm{D}}$ of the enzymeouabain complex can be calculated. The value obtained at $37^{\circ}-5.5 \times 10^{-7} \mathrm{M}$-agrees well with that calculated from the Scatchard plot (Fig. 1b) of the

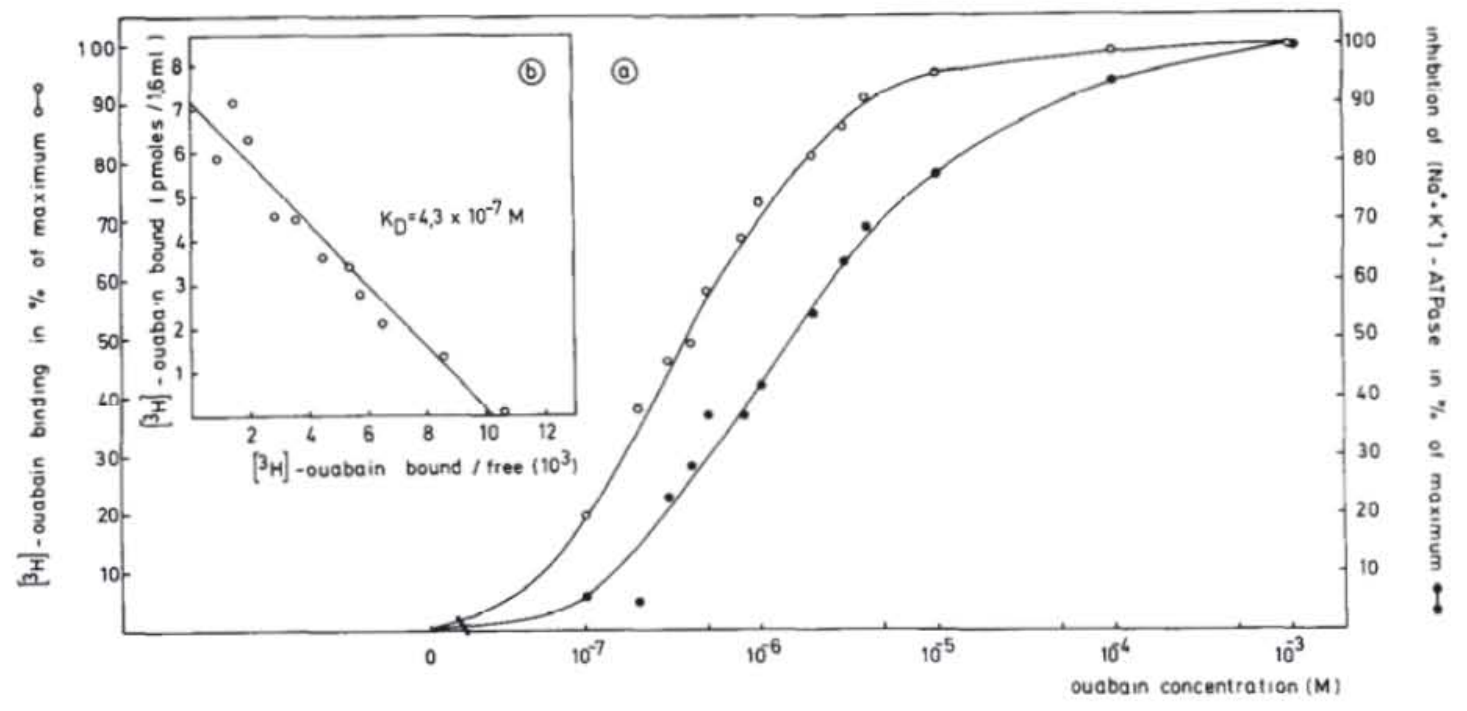

Fig. 1. Specific $\left({ }^{3} \mathrm{H}\right)$-ouabain binding to and ouabain-induced inhibition of $\left(\mathrm{Na}^{+}+\mathrm{K}^{+}\right)$-ATPase in cardiac cell membranes of chick embryos. (a) Cardiac cell membranes $\left[0.24 \mathrm{mg}\right.$ protein, $\left(\mathrm{Na}^{+}+\mathrm{K}^{*}\right)$ ATPase activity $0.16 \mu$ moles ATP hydrolyzed per min per mg protein at $\left.37^{\circ}\right]$ were incubated at $37^{\circ}$ in $3 \mathrm{mM} \mathrm{MgCl} 2,3 \mathrm{mM}$ imidazole $/ \mathrm{PO}_{4}, 2.8 \mathrm{nM}\left({ }^{3} \mathrm{H}\right)$-ouabain and increasing amounts of unlabelled ouabain $\left(1 \times 10^{-9}\right.$ to $\left.1 \times 10^{-3} \mathrm{M}\right)$ in $50 \mathrm{mM}$ imidazole $/ \mathrm{HCl}$ buffer, $\mathrm{pH} 7.25$, total volume $2.0 \mathrm{ml}$. After an incubation period of $2 \mathrm{hr}-$ representing equilibrium of oubain binding $-0.4 \mathrm{ml}$ of this incubation mixture was taken for determination of $\left(\mathrm{Na}^{+}+\mathrm{K}^{+}\right)$-ATPase activity (coupled optical assay), and the remaining $1.6 \mathrm{ml}$ was used for determination of $\left({ }^{3} \mathrm{H}\right)$-ouabain binding (rapid filtration method): $\left(\mathrm{Na}^{+}+\mathrm{K}^{+}\right)$-ATPase activity and $\left({ }^{3} \mathrm{H}\right)$-ouabain binding in the presence of $1 \times 10^{-3} \mathrm{M}$ ouabain were subtracted as non-specific. ( $\left.\mathrm{Na}^{+}+\mathrm{K}^{+}\right)$-ATPase was inhibited by $50 \%$ at a concentration $1.4 \mathrm{X}$ $10^{-6} \mathrm{M}$, while $\left({ }^{3} \mathrm{H}\right.$ )-ouabain binding was inhibited by $50 \%$ by $3.6 \times 10^{-7} \mathrm{M}$. (b) Scatchard plot analysis of $\left({ }^{3} \mathrm{H}\right)$-ouabain binding shown in (a). Calculations assuming one type of binding sites gave a dissociation constant $\left(K_{\mathrm{D}}\right)$ of $4.3 \times 10^{-7} \mathrm{M}$. 

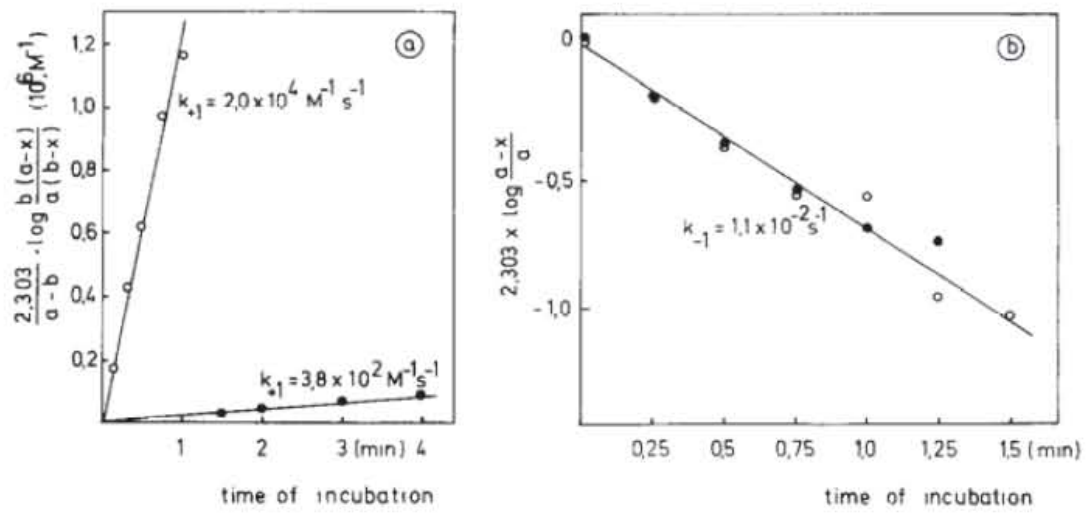

Fig. 2. $\left({ }^{3} \mathrm{H}\right)$-ouabain association to and dissociation from cardiac cell membranes of chick embryos. Influence of $\mathrm{K}^{+}$. (a) Determination of association rate constant $(k+1)$ : cardiac cell membranes $[0.24 \mathrm{mg}$ protein, $\left(\mathrm{Na}^{+}+\mathrm{K}^{+}\right)$-ATPase activity $0.14 \mu$ moles ATP hydrolyzed per min per mg protein at $37^{\circ}$, initial concentration of free binding sites $=a=5.7 \mathrm{nM}$ ] were incubated with $3 \mathrm{mM} \mathrm{MgCl}, 3 \mathrm{mM}$ imidazole/ $\mathrm{PO}_{4}, 5.6 \mathrm{nM}\left({ }^{3} \mathrm{H}\right)$-ouabain $(=b)$, with $3 \mathrm{mM} \mathrm{KCl}(-)$ or without $\mathrm{KCl}\left(\mathrm{O}^{-} \mathrm{O}\right)$ in $50 \mathrm{mM}$ imidazole $/ \mathrm{HCl} \mathrm{pH} 7.25$ at $37^{\circ}$, final volume $2.0 \mathrm{ml}$, for the stated times. The membrane-bound drug was measured after rapid filtration. $x=$ concentration of ouabain-receptor complex after reaction time. Substituting the experimental points into a second order equation yields a straight line, when plotted according to (a); the association rate constant $k_{+1}$ representing the slope of the curve. The initial concentration of free binding sites (a) has been determined by $\left({ }^{3} \mathrm{H}\right)$-ouabain binding under equilibrium conditions according to the experiment of Fig. 1. For further details see [11]. (b) Determination of dissociation rate constant $\left(k_{-1}\right)$ : Cardiac cell membranes $\left[58 \mathrm{mg}\right.$ protein, $\left(\mathrm{Na}^{+}+\mathrm{K}^{+}\right)$-ATPase activity $0.14 \mu$ moles ATP hydrolyzed per min per mg protein at $37^{\circ}$ ] have been incubated with $3 \mathrm{mM} \mathrm{MgCl}$. $3 \mathrm{mM}$ imidazole $/ \mathrm{PO}_{4}, 1.9 \times 10^{-8} \mathrm{M}\left({ }^{3} \mathrm{H}\right)$-ouabain in $50 \mathrm{mM}$ imidazole $/ \mathrm{HCl}, \mathrm{pH} 7.25$ at $37^{\circ}$ for $2 \mathrm{hr}$, final volume $12 \mathrm{ml}$. Thereafter, membranes have been centrifuged for $30 \mathrm{~min}$ at $100,000 \mathrm{~g}$, the sediment homogenized in $12 \mathrm{ml}$ water at $0^{\circ}$. A portion of this suspension $(0.2 \mathrm{ml}, 1.0 \mathrm{mg}$ protein) of drug-receptor complex has been incubated for the times shown, in $3 \mathrm{mM} \mathrm{MgCl}_{2}, 3 \mathrm{mM}$ imidazole/ $/ \mathrm{PO}_{4}, 1 \times 10^{-4} \mathrm{M}$ ouabain, with $3 \mathrm{mM} \mathrm{KCl}((-))$ or without $\mathrm{KCl}\left(\mathrm{O}_{-}-\mathrm{O}\right)$ in $50 \mathrm{mM}$ imidazole/ $\mathrm{HCl}$ buffer $\mathrm{pH} 7.25$ at $37^{\circ}$, final volume $2.0 \mathrm{ml}$. The membrane-bound drug was measured after rapid filtration. $a=$ amount of $\left({ }^{3} \mathrm{H}\right)$-ouabain bound at $t=0, x=$ amount of $\left({ }^{3} \mathrm{H}\right)$-ouabain dissociated at time $t$. Substituting the experimental points into first order equation yields a straight line, when plotted according to (b); the dissociation rate constant $k_{-1}$ being calculated from the slope of the curve [11].

ouabain-enzyme interaction at equilibrium. Association of ouabain is strongly reduced in the presence of $3 \mathrm{mM} \mathrm{K}^{+}$(Fig. 2a, while $\mathrm{K}^{+}$is without any influence on ouabain dissociation (Fig. 2b,

)

Specific $\left({ }^{3} \mathrm{H}\right)$-ouabain binding in cultured myocardial muscle and non mucle cells from chick embryos. For measurement of cellular $\left({ }^{3} \mathrm{H}\right)$-ouabain binding, monolayers of heart muscle cells have been incubated with $6.1 \times 10^{-8} \mathrm{M}\left({ }^{3} \mathrm{H}\right)$-ouabain at $37^{\circ}$. After different incubation periods, cell-bound $\left({ }^{3} \mathrm{H}\right)$-ouabain has been determined and the values plotted versus incubation time (Fig. 3, association, - Binding is almost completed within $30 \mathrm{~min}$; thereafter, only a small increase in cell-bound ouabain is observed. Using the same amount of $\left({ }^{3} \mathrm{H}\right)$ ouabain radioactivity, but high concentrations $\left(10^{-4} \mathrm{M}\right)$ of ouabain, little cell-bound radioactivity is measured (Fig. 3, association, $\mathbf{\Delta}-\mathbf{\Lambda}$ ), the amount being almost independent from the ouabain concentration chosen (tested for $10^{-4}-10^{-2} \mathrm{M}$ ouabain; experiments not shown). After an incubation period of $120 \mathrm{~min}$, the non-cell bound $\left({ }^{3} \mathrm{H}\right)$-ouabain was removed by washing the cells in ouabain-free medium, and dissociation of cell-bound ouabain has then been observed for the next $30 \mathrm{~min}$ (Fig. 3, dissociation, - $\boldsymbol{\Delta}-\boldsymbol{\Delta}$ ). Dissociation occurs rapidly: within five minutes, cells lose most of the $\left({ }^{3} \mathrm{H}\right)$-ouabain originally bound.

Concomitant with binding of $\left({ }^{3} \mathrm{H}\right)$-ouabain $\left(6.1 \times 10^{-8} \mathrm{M}\right)$ to the cells, part of the sodium pump molecules becomes inhibited (see Fig. 9), producing a decrease in cell- $\mathrm{K}^{+}$[control: $547 \pm 17$ nmoles $\mathrm{K}^{+} / \mathrm{mg}$ cell protein; cell- $\mathrm{K}^{+}$after incubation of the cells for 120 min with $\left({ }^{3} \mathrm{H}\right)$-ouabain $\left(6.1 \times 10^{-8} \mathrm{M}\right)$ : $453 \pm 16 \mathrm{nmoles} / \mathrm{mg}$ protein]. After washing of the cells thereafter in ouabain-free incubation medium, the $\mathrm{K}^{+}$-loss of the cells is completely reversible within the short period of $30 \mathrm{~min}(550 \pm 28 \mathrm{nmoles} / \mathrm{mg}$ protein; same experiment as described in Fig. 3), due to reactivation of the sodium pump molecules after dissociation of $\left({ }^{3} \mathrm{H}\right)$-ouabain (Fig. 3)

In a further experiment, chicken heart muscle cells have been incubated for $120 \mathrm{~min}$ with $\left({ }^{3} \mathrm{H}\right)$-ouabain $\left(3.4 \times 10^{-8} \mathrm{M}\right)$, as described for the experiment of Fig. 3. Specific ouabain binding (see below) of $560 \pm 10 \mathrm{fmoles} / \mathrm{mg}$ protein $(\mathrm{N}=3)$ has been obtained. In parallel, cells have been incubated with unlabelled ouabain at the same concentration for $120 \mathrm{~min}$, with subsequent washing of the cells in ouabain-free incubation medium, as described in the legend to Fig. 3. Thereafter, cells have been incubated with $\left({ }^{3} \mathrm{H}\right)$-ouabain $\left(3.4 \times 10^{-8} \mathrm{M}\right)$ for further $120 \mathrm{~min}$, and specific ouabain binding has then been 


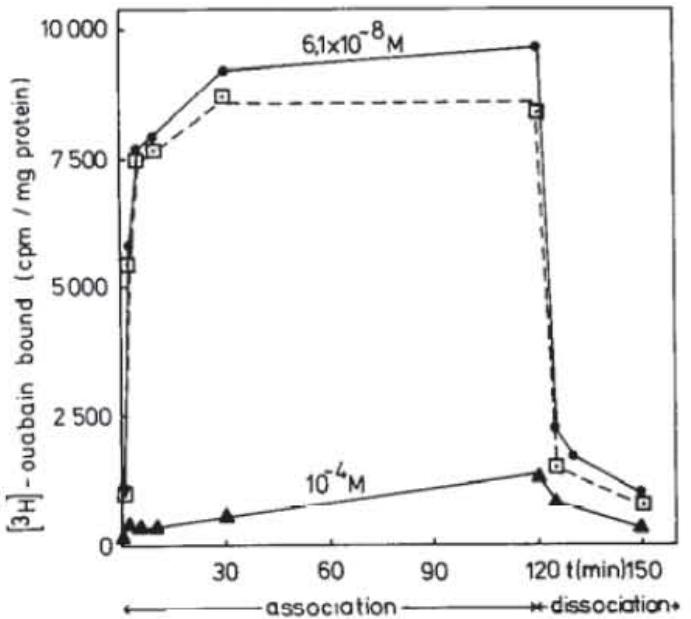

Fig. 3. Kinetics of $\left({ }^{3} \mathrm{H}\right)$-ouabain binding in cultured heart muscle cells from chicken embryos. Heart muscle cells have been incubated for $4 \mathrm{hr}$ in serum-supplemented $(2.5 \%$ fetal calf serum, $2.5 \%$ horse serum), Hepes-buffered CMRL 1415 ATM medium $\left(\left[\mathrm{K}^{+}\right]=0.75 \mathrm{mM}\right)$ at $37^{\circ}$. Thereafter. $\left({ }^{3} \mathrm{H}\right)$-ouabain has been added, the ouabain concentration being $6.1 \times 10^{-8} \mathrm{M}(-)$ and $1 \times 10^{-4} \mathrm{M}(\boldsymbol{\Lambda}-\mathbf{\Lambda})$ resp. $\left(3.3 \times 10^{6} \mathrm{cpm}\left({ }^{3} \mathrm{H}\right)\right.$-ouabain/flask, $0.65 \mathrm{mg}$ protein/flask, incubation volume $4.1 \mathrm{ml}$ ).

Association: at the times indicated, non cell bound $\left({ }^{3} \mathrm{H}\right)$-ouabain has been removed by repeated washing of the cells, and the cell-bound radioactivity has been determined.

Dissociation: After preincubation period, $\left({ }^{3} \mathrm{H}\right)$-ouabain $\left(3.3 \times 10^{6} \mathrm{cpm} /\right.$ flask, $\left.6.1 \times 10^{-8} \mathrm{M}, \boldsymbol{\Delta}-\boldsymbol{\Lambda} 10^{-4} \mathrm{M}\right)$ has been added to the cells for $120 \mathrm{~min}$. Thereafter, cells have been washed five times $\left(37^{\circ}\right)$ with incubation medium without ouabain and have been further incubated in ouabain-free medium. Cell-bound $\left({ }^{3} \mathrm{H}\right)$-ouabain has been measured at the times indicated in abscissa. At $t=150 \mathrm{~min}$, $\left({ }^{3} \mathrm{H}\right)$-ouabain concentration in incubation medium was $1.3 \times 10^{-11} \mathrm{M}(-)$ and $6 \times 10^{-11} \mathrm{M}(\boldsymbol{\Delta}-\mathbf{\Delta})$ respectively. For calculation of specific $\left({ }^{3} \mathrm{H}\right)$-ouabain binding (- - $)$, cell-bound $\left({ }^{3} \mathrm{H}\right)$-radioactivity in the presence of $10^{-4} \mathrm{M}$ ouabain has been subtracted from cell bound $\left({ }^{3} \mathrm{H}\right)$-radioactivity in the presence of $6.1 \times 10^{-8} \mathrm{M}$ ouabain.

Values are given as mean from closely correlating triplicates. For preparation and cultivation of cardiac muscle cells, the hearts of 142 chicken embryos (10 day-old) have been used. Cells have been seeded in 51 plastic culture flasks $\left(25 \mathrm{~cm}^{2}\right.$ each) at a cell density of $100,000 / \mathrm{cm}^{2}$.

determined. A value of $520 \pm 60 \mathrm{fmoles} / \mathrm{mg}$ protein $(\mathrm{N}=3)$ has been obtained, representing $93 \%$ of control binding. Therefore, nearly all of unlabelled ouabain has been washed out within $60 \mathrm{~min}$, and could be replaced by $\left({ }^{3} \mathrm{H}\right)$-ouabain.

The capability of the cells to bind ouabain is lost after heat denaturation: in Table 1 , binding of $\left({ }^{3} \mathrm{H}\right)$-ouabain at $37^{\circ}$ is compared in normal and heat-shocked cells. In heat-shocked cells, binding in the presence of $9 \times 10^{-8} \mathrm{M}\left({ }^{3} \mathrm{H}\right)$-ouabain is reduced to $7 \%$ of control value. In contrast, at $10^{-3} \mathrm{M}$ ouabain, no difference can be found concerning cellbound radioactivity in both groups, the small amount of bound $\left({ }^{3} \mathrm{H}\right)$-ouabain being equal to that of heatshocked cells in the presence of $9 \times 10^{-8} \mathrm{M}$ ouabain. The denaturation process used inactivates the uptake of $\left({ }^{86} \mathrm{Rb}^{+}\right)$into the cells by more than $95 \%$, and it produces a loss of protein of about $8 \%$.

Ouabain binding to chick heart muscle cells is strongly influenced by $\mathrm{K}^{+}$ions: the experiment of Fig. $4\left(\mathrm{O}^{-} \mathrm{O}\right)$ demonstrates $\left({ }^{3} \mathrm{H}\right)$-ouabain binding $\left(6.2 \times 10^{-8} \mathrm{M}\right.$, incubation period $4 \mathrm{hr}$ at $\left.37^{\circ}\right)$ in the presence of various $\mathrm{K}^{+}$concentrations in incubation medium. Maximum binding is obtained at $0.5 \mathrm{mM}$ $\mathrm{K}^{+}$. Increasing the $\mathrm{K}^{+}$concentration ( $\geqq 1 \mathrm{mM}$ ) decreases $\left({ }^{3} \mathrm{H}\right)$-ouabain binding-in agreement with the effect of $\mathrm{K}^{+}$on $\left({ }^{3} \mathrm{H}\right)$-ouabain binding in isolated cardiac membranes (see Fig. 2)-due to a direct interaction of the cation with the binding process (see next paragraph). The decreases of $\left({ }^{3} \mathrm{H}\right)$-ouabain binding at $\mathrm{K}^{+}$concentrations lower than $0.5 \mathrm{mM}$, as found in intact cardiac cells:(Fig. 4), has not been observed in cardiac cell membranes. The reason for this decrease is unknown, it may be due to partial damage of the cells during incubation in very low or even zero $\mathrm{K}^{+}$concentration in the medium. At $\left[\mathrm{K}^{+}\right]=20 \mathrm{mM}$ - the highest concentration used$84 \%$ of maximal binding is abolished. Further inhibition - up to $95 \%$ - is obtained by addition of $10^{-4} \mathrm{M}$ ouabain (see legend to Fig. 4).

Applying the criteria for specific and non specific binding of cardiac glycosides to isolated cell membranes [13], description of $\left({ }^{3} \mathrm{H}\right)$-ouabain binding in intact myocardial muscle cells is possible: binding of ouabain to specific binding sites is abolished by heat denaturation of the cells, by addition of excesss of unlabeled ouabain, and in the presence of high $\mathrm{K}^{+}$ concentrations. The remaining amount of $\left({ }^{3} \mathrm{H}\right)$ radioactivity bound to the cells after applying these procedures then represents non specific binding of $\left({ }^{3} \mathrm{H}\right)$-ouabain. The results of Figs. 3 and 4 , and those of Table 1 clearly demonstrate that a large portion of $\left({ }^{3} \mathrm{H}\right)$-ouabain is specifically bound to these cells. This portion can be calculated by subtracting the non specifically bound $\left({ }^{3} \mathrm{H}\right)$-ouabain radioactivity from the total amount of $\left({ }^{3} \mathrm{H}\right)$-ouabain bound to the cells.

Table 1. Comparison of $\left({ }^{3} \mathrm{H}\right)$-ouabain binding in normal and heat-shocked chicken heart muscle cells

Control Heat-shocked cells

\section{$\left({ }^{3} \mathrm{H}\right)$-ouabain binding}

(cpm/mg protein)

$\begin{array}{lrr}9 \times 10^{-8} \mathrm{M} \text { ouabain } & 31,850 & 2279 \\ 10^{-3} \mathrm{M} \text { ouabain } & 1507 & 2152 \\ \begin{array}{l}{ }^{86} \mathrm{Rb}^{+}+\mathrm{K}^{+} \text {)-uptake } \\ \text { nmoles } / \mathrm{mg} \text { protein } \times \text { min) }\end{array} & 23.9 & <0.1 \\ \begin{array}{l}\text { ell protein } \\ \text { mg/flask) }\end{array} & 1.93 & 1.78\end{array}$

Heart muscle cells have been incubated for $60 \mathrm{~min}$ in standard medium (see Materials and Methods) at $37^{\circ}$ (control) and $60^{\circ}$ (heat-shocked cells) respectively (Incubation A).

$\left({ }^{3} \mathrm{H}\right)$-ouabain binding. After incubation $\mathrm{A},\left({ }^{3} \mathrm{H}\right)$-ouabain $\left(4.5 \times 10^{6} \mathrm{cpm} / \mathrm{flask}\right)$ has been added to the standard medium, giving final ouabain-concentrations of $9 \times 10^{-6}$ and $10^{-3} \mathrm{M}$ respectively. Cell-bound $\left({ }^{3} \mathrm{H}\right)$-ouabain has been determined after $4 \mathrm{hr}$ of $\left({ }^{3} \mathrm{H}\right)$-ouabain incubation at $37^{\circ}$.

$\left({ }^{86} \mathrm{Rb}^{+}+\mathrm{K}^{+}\right)$-uptake. After incubation $\mathrm{A}$, cells have been incubated for further $4 \mathrm{hr}$ in standard medium at $37^{\circ}$. Thereafter, ${ }^{86} \mathrm{Rb}^{+}\left(2.8 \times 10^{6} \mathrm{cpm} / \mathrm{flask}\right)$ has been added and uptake has been measured for $10 \mathrm{~min}$. 
The kinetics of this specific $\left({ }^{3} \mathrm{H}\right)$-ouabain binding are shown in Fig. $3(--)$ : equilibrium of binding is achieved within $30 \mathrm{~min}$, being stable throughout the whole incubation period of $120 \mathrm{~min}$ in the experiment of Fig. 3 and-in other experiments (not shown)for at least $8 \mathrm{hr}$. It should be pointed out that-if not stated otherwise-all measurements of specific $\left({ }^{3} \mathrm{H}\right)$-ouabain binding have been carried out in the presence of $0.75 \mathrm{mM} \mathrm{K}^{+}$, to achieve almost maximal binding without irreversible damage to the cells.

Specific $\left({ }^{3} \mathrm{H}\right)$-ouabain binding has been also found in cardiac non muscle cells obtained from the same heart preparations, mainly consisting of fibroblasts and endothelial cells: specific and non specific binding can he distinguished according to the criteria mentioned, with a large portion of $\left({ }^{3} \mathrm{H}\right)$-ouabain being specifically bound; also in the case of cardiac non muscle cells, equilibrium of specific $\left({ }^{3} \mathrm{H}\right)$-ouabain binding is obtained within $30 \mathrm{~min}$, being stable at least for $8 \mathrm{hr}$ (experiments not shown). Again, $\mathrm{K}^{+}$ reduces ouabain binding in a concentration-dependent manner (Fig. 4.

Association and dissociation rate constants for specific $\left({ }^{3} \mathrm{H}\right)$-ouabain binding in cultured heart cells from chick embryos. In cardiac cell membranes from chick embryos, specific binding of $\left({ }^{3} \mathrm{H}\right)$-ouabain follows second order kinetics (Fig. 2a), while dissociation of the ouabain-binding site complex can be described by first order kinetics (Fig. 2b), as shown by Erdmann and Schoner [11] for the cardiac glycoside-receptor interaction in a variety of mem- brane preparations from various tissues and species. Can these kinetics also be applied to ouabain binding in intact cardiac cells? If this holds true, then binding could be described by the following equation: $[\mathrm{Ou}]+[\mathrm{BS}] \underset{k_{-1}}{\stackrel{k+1}{\rightleftarrows}}[\mathrm{OuBS}]$, where Ou is ouabain, BS the binding site or receptor for cardiac glycosides, OuBS the ouabain-binding site-complex, $k_{+1}$ the association rate constant and $k_{-1}$ the dissociation rate constant. The dissociation constant $K_{\mathrm{D}}$ can then be calculated from the respective rate constants $K_{\mathrm{D}}=\left(k_{-1}\right) /\left(k_{+1}\right)$.

In Fig. 5, the kinetics of association (Fig. 5a) and dissociation (Fig. 5b) process for specific $\left({ }^{3} \mathrm{H}\right)$-ouabain binding to chick heart muscle cells at $37^{\circ}$ are demonstrated. The association process can be described by second order kinetics, fitting the following equation: $k_{+1}=\frac{2.303}{(a-b) \cdot t} \cdot \log \frac{b(a-x)}{a(b-x)}$ (Fig. $5 \mathrm{c})$, where $a$ is the initial concentration of ouabain in incubation medium, $b$ the concentration of binding sites, and $x$ the concentration of ouabain-binding site-complexes after reaction time $t$. The association rate constant $k_{+1}$ can be calculated from the slope of the curve presented in Fig. 5(c), being $1.5 \times 10^{4} \mathrm{M}^{-1} \mathrm{~s}^{-1}$ in this experiment.

The dissociation process fits first order kinetics, as can be seen by the straight line obtained when plotting the data of Fig. 5(b) according to $k_{-1}=$ $-2.303 \times \log (a-x) /(a) \times(1) /(t)$ (Fig. 5d), where $a$ is the amount of ouabain-binding site-complexes

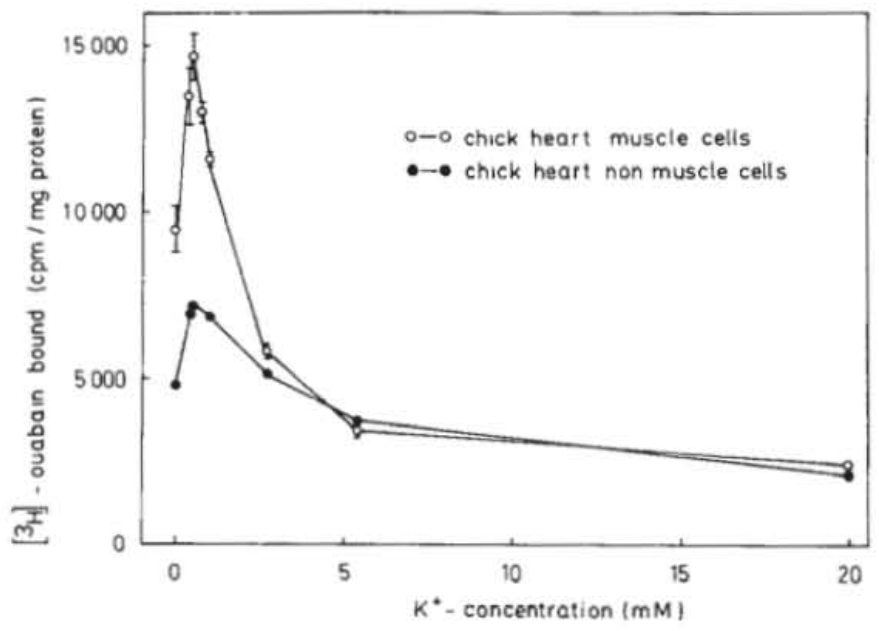

Fig. 4. $\left({ }^{3} \mathrm{H}\right)$-ouabain binding to cultured heart cells from chicken embryos. Influence of potassium ions. Musclc and non muscle cells from hearts of chicken embryos have been prepared and cultivated as described in methods. Cells have been incubated for $4 \mathrm{hr}$ in standard medium with $\mathrm{K}^{+}$-concentrations as indicated (see abscissa), in the presence of $\left({ }^{3} \mathrm{H}\right)$-ouabain. Temperature $37^{\circ}$.

Radioactivity, ouabain concentration and cell protein per flask (incubation vol $4.1 \mathrm{ml}$ ): Heart muscle cells: $3.4 \times 10^{6} \mathrm{cpm}, 6.2 \times 10^{-8} \mathrm{M}, 0.40 \mathrm{mg}$; heart non muscle cells: $3.7 \times 10^{5} \mathrm{cpm}, 3.6 \times 10^{-8} \mathrm{M}, 0.80 \mathrm{mg}$ Unspecific $\left({ }^{3} \mathrm{H}\right.$ )-ouabain binding (cpm/mg protein): Heart muscle cells ([ouabain] $=10^{-4} \mathrm{M}$ ): 1242 $\left(\left[\mathrm{K}^{+}\right]=0 \mathrm{mM}\right), 855\left(\left[\mathrm{~K}^{+}\right]=5.4 \mathrm{mM}\right), 730\left(\left[\mathrm{~K}^{+}\right]=20 \mathrm{mM}\right)$. Heart non muscle cells $([$ ouabain $]=$ $\left.10^{-2} \mathrm{M}\right): 895\left(\left[\mathrm{~K}^{+}\right]=20 \mathrm{mM}\right)$.

Values are mean $\pm \mathrm{SD}(n=3)$ (heart muscle cells) and means from closely correlating duplicates (heart non muscle cells) respectively.

For preparation and cultivation of cardiac muscle cells, the hearts of 90 chicken embryos (10-day-old) have been used. Cells have been seeded in 33 plastic culture flasks $\left(25 \mathrm{~cm}^{2}\right.$ each) at a cell density of $100,000 / \mathrm{cm}^{2}$. Heart non muscle cells have been obtained from the same preparation, after 1 subcultivation, and have been also seeded in 33 plastic culture flasks ( $25 \mathrm{~cm}^{2}$ each). 

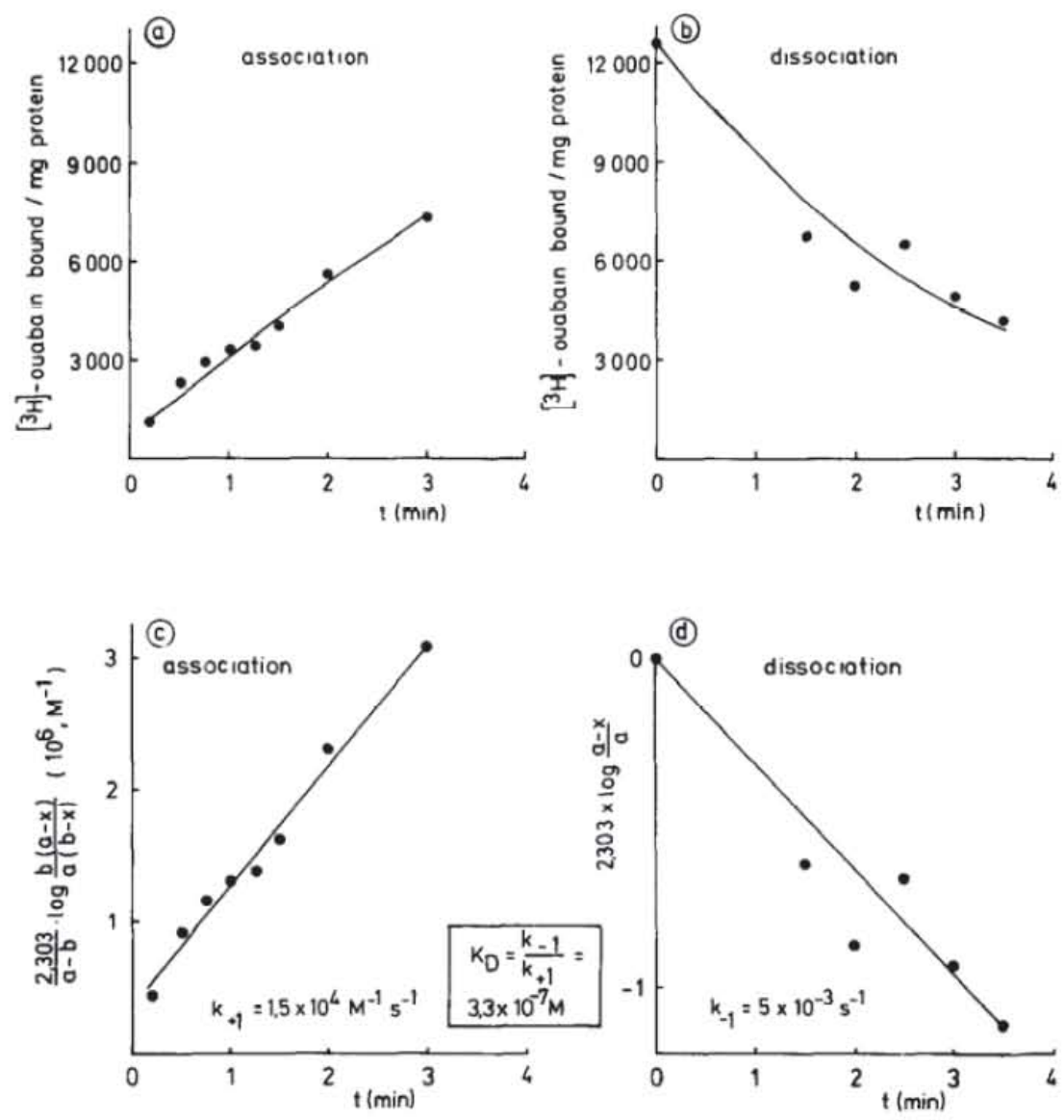

Fig. 5. Determination of association and dissociation rate constants of $\left({ }^{3} \mathrm{H}\right)$-ouabain binding to cultured chick heart muscle cells. $\left({ }^{3} \mathrm{H}\right.$ )-ouabain association (a) and dissociation (b) experiments have been carried out as described in legend to Fig. 3. Unspecific $\left({ }^{3} \mathrm{H}\right)$-ouabain binding has been determined in the presence of $10^{-4} \mathrm{M}$ ouabain; the specifically cell-bound $\left({ }^{3} \mathrm{H}\right)$-ouabain is given on the ordinates as $\mathrm{cpm} / \mathrm{mg}$ protein. $3.6 \times 10^{6} \mathrm{cpm}\left({ }^{3} \mathrm{H}\right)$-ouabain $\left(6.2 \times 10^{-8} \mathrm{M}\right)$ and $0.56 \mathrm{mg}$ protein per flask, incubation volume $4.1 \mathrm{ml}$, temperature $37^{\circ}$. Values are given as mean from closely correlating duplicates. In addition to the measurements shown in (a) and (b), concentration dependent, specific $\left({ }^{3} \mathrm{H}\right)$-ouabain binding under equilibrium conditions with subsequent Scatchard plot analysis has been carried out within the same experiment, according to the experiment of Fig. 8. The following values have been obtained: $B=2.7$ pmoles $/ \mathrm{mg}$ protein, $K_{\mathrm{D}}=1.1 \times 10^{-7} \mathrm{M}$. In (c) and (d), the data of the association and dissociation experiments have been plotted to fit the equations for second order kinetics (c, association) and first order kinetics (d, dissociation) respectively. For further explanation see text. (c): $a=$ Initial concentration of ouabain in incubation medium $=6.2 \times 10^{-8} \mathrm{M} . b=$ Total amount of ouabain binding sites $/ 4.1 \mathrm{ml} \triangleq 0.41 \times 10^{-9} \mathrm{M}$ (determined by Scatchard plot analysis). $x=$ Amount of ouabain-binding site-complexes $/ 4.1 \mathrm{ml}$ after reaction time $t$. (d): $a=$ Total amount of ouabain-binding site-complexes $/ 4.1 \mathrm{ml}$ at $t=0 . a-x=$ amount of ouabain-binding site-complexes $/ 4.1 \mathrm{ml}$ at reaction time t. Calculations are based on the assumption that binding sites of the cells grown as monolayer are as freely accessible to ouabain molecules during assay conditions as the binding sites of cells homogeneously suspended in incubation medium. In (c), regression analysis has been done fitting the equation $y=$ $m x+b$. According to second order kinetics (see text), $b$ should be zero. This, however, is not the case in the experiment of (c), probably due to experimental error (see (a)).

For preparation and cultivation of cardiac muscle cells, the hearts of 164 chicken embryos (10-dayold) have been used. Cells have been seeded in 48 plastic culture flasks $\left(25 \mathrm{~cm}^{2}\right.$ each) at a seeding density of 100,000 cells $/ \mathrm{cm}^{2}$.

at $t=0$, and $x$ the amount dissociated from the binding sites at reaction time $t$. The dissociation rate constant $k_{-1}$ can then be calculated from the slope of the curve, being $5 \times 10^{-3} \mathrm{~s}^{-1}$ in this experiment. From $K_{\mathrm{D}}=\left(k_{-1}\right) /\left(k_{+1}\right)$, a dissociation constant of $3.3 \times 10^{-7} \mathrm{M}$ is obtained. This value is in good agreement with the $K_{\mathrm{D}}$ of $1.1 \times 10^{-7} \mathrm{M}$, found within the same experiment by equilibrium $\left({ }^{3} \mathrm{H}\right)$-ouabain binding using Scatchard plot analysis [32].
The reduction of $\left({ }^{3} \mathrm{H}\right)$-ouabain binding under equilibrium conditions by $\mathrm{K}^{+}$ions (Fig. 4) can be explained by the $\mathrm{K}^{+}$-induced slowing of association velocity, while a considerable effect of $\mathrm{K}^{+}$ions on dissociation velocity is absent (Fig. 6). The temperature dependence of association and dissociation rate constants-within the range between 9 and $36^{\circ}$-is shown in Fig. 7(a). The rate of dissociation $(\boldsymbol{\Delta}-\mathbf{\Delta})$ is more sensitive to temperature than the 
rate of association (-). This disproportionate change of the rate constants with temperature results in an increasing equilibrium constant $(K)$ with increasing temperature (Fig. $7 \mathrm{~b}$ ). From the slopes of the Arrhenius plots (Fig. 7), the activation energies for association and dissociation processes can be calculated as $53 \mathrm{~kJ} / \mathrm{mol}\left(Q_{10}=2.0\right)$ and $97 \mathrm{~kJ} / \mathrm{mol}$ $\left(Q_{1 \cdots}=3.6\right)$ respectively. and for equilibrium binding as $-4.5 \mathrm{~kJ} / \mathrm{mol}\left(Q_{10}=\mathrm{i} .8\right)$.

Similar results as described in Figs. 5-7 have also been obtained with heart non muscle cells from chick embryos: $\left({ }^{3} \mathrm{H}\right)$-ouabain association follows second order kinetics, dissociation is a first order process; both processes are strongly temperature-dependent. In Table 2. the results concerning muscle and non muscle cells have been listed for comparison.

Quantification of the number of cardiac glycoside binding sites in cardiac muscle and non muscle cells from chick embryos. The results of the association and dissociation experiments described in the preceding paragraph are compatible with binding of $\left({ }^{3} \mathrm{H}\right)$-ouabain to specific binding sites. For determination of the number of these binding sites $/ \mathrm{mg}$ cell

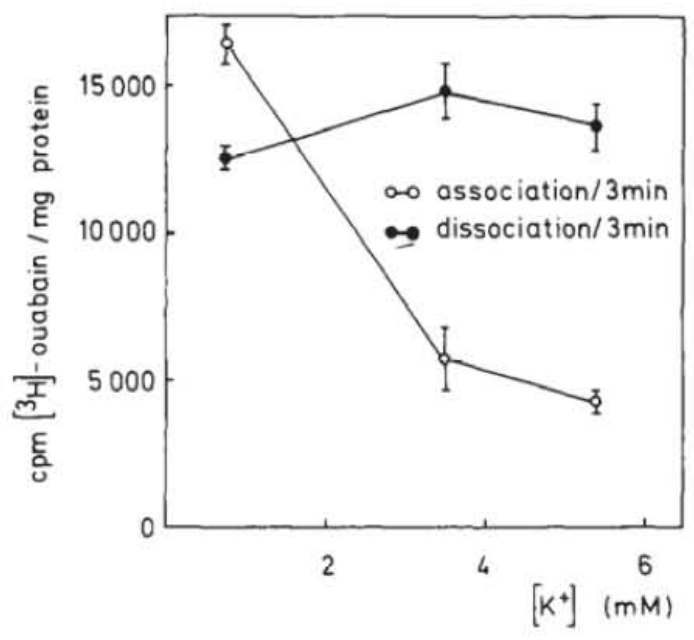

Fig. 6. Influence of $\mathrm{K}^{-}$on association and dissociation processes of $\left({ }^{3} \mathrm{H}\right)$-ouabain binding in heart muscle cells from chicken embryos. Measurements have been carried out in standard medium, with the $\mathrm{K}^{-}$-concentration as indicated (see abscissa). as described in legends to Figs. 3 and 5. For measurement of association velocity of $\left({ }^{3} \mathrm{H}\right)$ ouabain binding. cells have been incubated for $3 \mathrm{~min}$ with $\left({ }^{3} \mathrm{H}\right)$-ouabain $\left(3.6 \times 10^{6} \mathrm{cpm} / \mathrm{flask}, 6.7 \times 10^{-8} \mathrm{M}\right)$. Thereafter. specifically bound $\left({ }^{3} \mathrm{H}\right)$-ouabain has been determined (ordinate). For measurement of dissociation velocity. cells have been incubated for $120 \mathrm{~min}$ at $\left[\mathrm{K}^{-}\right]=0.75 \mathrm{mM}$ with ('H)-ouabain $\left(3.6 \times 10^{6} \mathrm{cpm} /\right.$ flask, $\left.6.7 \times 10^{-x} \mathrm{M}\right)$. Thereafter. cells have been washed five times and then been further incubated in ouabain-free standard medium with $\mathrm{K}^{-}$-concentrations as indicated (see abscissa). The amount of $\left({ }^{3} \mathrm{H}\right)$-ouabain dissociated from its binding sites within $3 \mathrm{~min}$ has been determined (ordinate). Temperature $37^{\circ}$. incubation volume $4.1 \mathrm{ml}: 1.30 \mathrm{mg}$ protein/flask. Unspecific $\left({ }^{3} \mathrm{H}\right)$-ouabain binding has been determined in the presence of $10^{-3} \mathrm{M}$ ouabain. Values are given as mean $=\mathrm{S} . \mathrm{D}$. $(\mathrm{N}=3)$. For preparation and cultivation of cardiac muscle cells. the hearts of 98 chicken embryos (12-day-old) have been used. Cells have been seeded in 53 plastic culture flasks $\left(25 \mathrm{~cm}^{2}\right.$ each) at cell densities of $116.000 / \mathrm{cm}^{2}$.

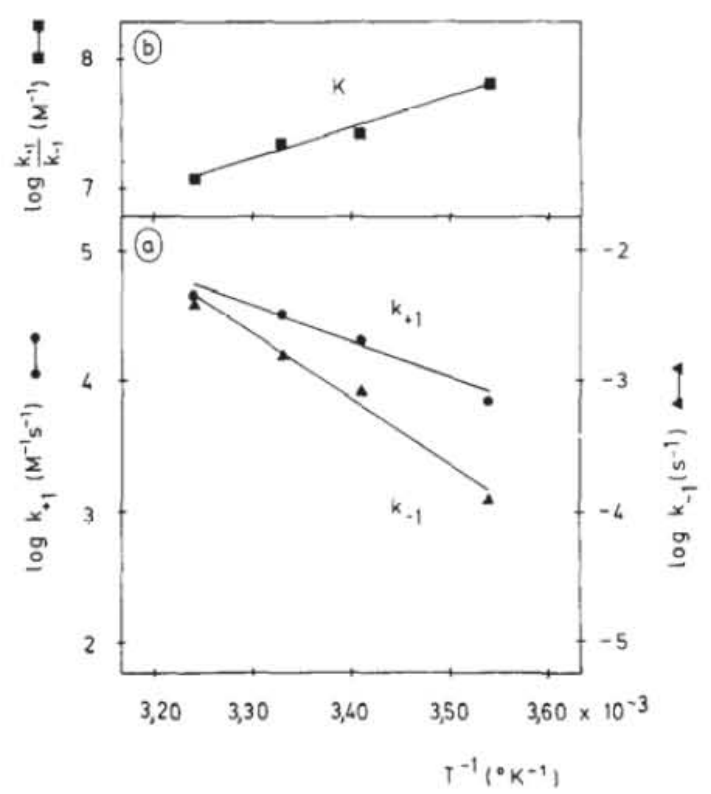

Fig. 7. Temperature dependence of specific $\left({ }^{3} \mathrm{H}\right)$-ouabain binding to chick heart muscle cells in culture. (a) Arrhenius plot of the rate constants of association (-) and dissociation $(\boldsymbol{\Lambda}-\boldsymbol{\Lambda})$ of specific $\left({ }^{3} \mathrm{H}\right)$-ouabain binding. Measurements have been carried out at 9.5, 20,27 and $36^{\circ}$ in standard medium. $\left({ }^{3} \mathrm{H}\right)$-ouabain association has been measured within $t=0.25$ and $t=3 \mathrm{~min} .\left({ }^{3} \mathrm{H}\right)$-ouabain dissociation for $3 \mathrm{~min}$ as described in legend of Fig. 6. In addition, concentration dependent, specific $\left({ }^{3} \mathrm{H}\right)$-ouabain binding under equilibrium conditions with subsequent Scatchard plot analysis has been carried out within the same experiment, according to the experiment of Fig. 8. The data obtained allow calculation of association and dissociation rate constants. as demonstrated in the experiment of Fig. 5. Incubation volume $4.1 \mathrm{ml} ; 0.30 \mathrm{mg}$ protein/flask: $3.6 \times 10^{6} \mathrm{cpm} \quad\left({ }^{3} \mathrm{H}\right)$-ouabain $/$ flask, [ouabain] $=3.5 \times$ $10^{-8} \mathrm{M}$. Unspecific $\left({ }^{3} \mathrm{H}\right)$-ouabain has been determined in the presence of $10^{-4} \mathrm{M}$ ouabain. Values are mean from closely correlating duplicates. Arrhenius plot analysis: activation energy of $\left({ }^{3} \mathrm{H}\right)$-ouabain association process: $12.6 \mathrm{kcal} / \mathrm{mol}\left(52.9 \mathrm{~kJ} / \mathrm{mol}, Q_{10}=2.0\right)$; activation energy of $\left({ }^{3} \mathrm{H}\right)$-ouabain dissociation process: $23.1 \mathrm{kcal} / \mathrm{mole}$ $\left(96.7 \mathrm{~kJ} / \mathrm{mol} . Q_{10}=3.6\right)$. (b) Temperature dependence of the equilibrium constant $K$ of the ouabain-binding site-complex. The equilibrium constant was calculated from the ratio of the rate constants $\left(k_{-} / k_{-1}\right)$ of (a). Arrhenius plot analysis yields an activation energy of $-10.7 \mathrm{kcal} / \mathrm{mol}\left(-44.8 \mathrm{~kJ} / \mathrm{mol} . Q_{10}=1.8\right)$. For preparation and cultivation of cardiac muscle cells, the hearts of 117 chicken embryos (10-day-old) have been used. Cells have been seeded in 50 plastic culture flasks $\left(25 \mathrm{~cm}^{2}\right.$ each) at a cell density of $100,000 / \mathrm{cm}^{2}$.

protein. ouabain binding under equilibrium conditions has been measured at different ouabain concentrations in muscle as well as in non muscle cells (Fig. 8a). At $10^{-6} \mathrm{M}$, saturation of binding is reached in both cell types. When plotting the data of Fig. 8 (a) according to the method of Scatchard [32] as shown in Fig. 8(b), straight lines are obtained for both cell types, indicative of single classes of binding sites. The slopes of the lines represent the dissociation constants $K_{\mathrm{D}}$, the intercepts with the $y$-axis the number of binding sites $(B)$. Table 3 summarizes mean values for $K_{\mathrm{D}}$ and $B$ for muscle and non muscle 
Table 2. Binding parameters of $\left({ }^{3} \mathrm{H}\right)$-ouabain binding to cardiac muscle and non muscle cells in culture, prepared from chicken embryos

\begin{tabular}{lcc}
\hline$\left({ }^{3} \mathrm{H}\right)$-ouabain binding parameters & Heart muscle cells & $\begin{array}{c}\text { Heart non } \\
\text { muscle cells }\end{array}$ \\
\hline $\begin{array}{l}\text { Association rate constant } k_{+1} \\
\left(\mathrm{M}^{-1} \mathrm{~s}^{-1}\right), 37^{\circ}\end{array}$ & $(3.2 \pm 1.6) \times 10^{4}$ & $(2.2 \pm 1.6) \times 10^{4}$ \\
$\begin{array}{l}\text { Dissociation rate constant } k_{-1}\left(\mathrm{~s}^{-1}\right), \\
37^{\circ}\end{array}$ & $(4.5 \pm 0.8) \times 10^{-3}$ & $(2.8 \pm 1.6) \times 10^{-3}$ \\
$\begin{array}{l}\text { Dissociation constant } K_{\mathrm{D}}=k_{-1} / k_{+1} \\
(\mathrm{M}), 37^{\circ}\end{array}$ & $(1.9 \pm 1.3) \times 10^{-7}$ & $(1.3 \pm 0.3) \times 10^{-7}$ \\
$\begin{array}{l}\text { Activation energy of association } \\
\text { process }(\mathrm{kJ} / \mathrm{mol}), 9-36^{\circ}\end{array}$ & $56.1 \pm 10.4\left(Q_{10} \sim 2.1\right)$ & $36.5\left(Q_{10} \sim 1.7\right)$ \\
$\begin{array}{l}\text { Activation energy of dissociation } \\
\text { process }(\mathrm{kJ} / \mathrm{mol}), 9-36^{\circ}\end{array}$ & $106.5 \pm 20.4\left(Q_{10} \sim 4.2\right)$ & $92.5\left(Q_{10} \sim 3.8\right)$ \\
$\begin{array}{l}\text { Activation energy of equilibrium } \\
\text { binding }(\mathrm{kJ} / \mathrm{mol}), 9-36^{\circ}\end{array}$ & $-62.7 \pm 31.1\left(Q_{10} \sim 2.5\right)$ & $-56.2\left(Q_{10} \sim 2.4\right)$ \\
\hline
\end{tabular}

Results have been obtained from experiments as described in Figs. 5 and 7 . Heart muscle cells: Mean \pm S.D. $(N=3-5)$; heart non muscle cells: Mean \pm S.D. $(N=3)$ and mean values from duplicates respectively.

cells: similar values for $K_{\mathrm{D}}$ are found in both cell types, demonstrating no substantial difference in the affinity of the binding sites for ouabain. Based on cell protein, the number of binding sites is about $25 \%$ higher in muscle than in non muscle cells.

Increasing the $\mathrm{K}^{+}$concentration in the medium is without influence on the number of binding sites, but increases $K_{\mathrm{D}}$ (heart muscle cells, $\left[\mathrm{K}^{+}\right]=$ $0.75 \mathrm{mM}: K_{\mathrm{D}}=1.9 \times 10^{-7} \mathrm{M}, \quad B=3.3$ pmoles $/ \mathrm{mg}$ protein; $\left[\mathrm{K}^{+}\right]=2.5 \mathrm{mM}: K_{\mathrm{D}}=3.5 \times 10^{-7} \mathrm{M}, \quad B=$ 3.3 pmoles $/ \mathrm{mg}$ protein. Heart non muscle cells, $\left[\mathrm{K}^{+}\right]=0.75 \mathrm{mM}: K_{\mathrm{D}}=2.1 \times 10^{-7} \mathrm{M}, B=1.8$ pmoles $/ \mathrm{mg}$ protein; $\left[\mathrm{K}^{+}\right]=3.5 \mathrm{mM}: K_{\mathrm{D}}=3.4 \times$ $10^{-7} \mathrm{M}, B=1.9 \mathrm{pmoles} / \mathrm{mg}$ protein).

Correlation between specific ouabain binding and inhibition of active $\left({ }^{86} \mathrm{Rb}^{+}+\mathrm{K}^{+}\right)$-influx in cardiac muscle and non muscle cells from chick embryos. A specific binding site may only be classified as a receptor, when occupation of the binding site by its ligand initiates a physiological or pharmacological effect. We have therefore correlated specific $\left({ }^{3} \mathrm{H}\right)$ ouabain binding with inhibition of the sodium pump-as measured by $\left({ }^{86} \mathrm{Rb}^{+}+\mathrm{K}^{+}\right)$-influx $[37,38]$-and its consequences on intracellular sodium and potassium levels: cardiac muscle and non muscle cells have been incubated at different ouabain concentrations under identical conditions, as it has been carried out for $\left({ }^{3} \mathrm{H}\right)$-ouabain binding (incubation period $4 \mathrm{hr}, 37^{\circ},\left[\mathrm{K}^{+}\right]=0.75 \mathrm{mM}$ ). In both cell types (Figs. $9 \mathrm{a}$ and b), ${ }^{86} \mathrm{Rb}^{+}+\mathrm{K}^{+}$)-uptake is inhibited by ouabain in a concentration dependent manner. Maximal inhibition is more than $95 \%$, demonstrating that - at this low $\mathrm{K}^{+}$concentration-more than $95 \%$ of ${ }^{86} \mathrm{Rb}^{+}+\mathrm{K}^{+}$)-influx represents active transport mediated by the sodium pump. Half maximal inhibition occurs at $5.8 \times 10^{-7} \mathrm{M}$ (heart muscle cells) and $2.6 \times 10^{-7} \mathrm{M}$ (heart non muscle cells) resp. (Table 3). As consequence of ouabain-induced inhibition of active cation transport, cellular sodium concentration increases, and cellular potassium level decreases, the $\mathrm{EC}_{50}$ values being close to the ouabain concentration producing $50 \%$ inhibition of $\left({ }^{86} \mathrm{Rb}^{+}+\mathrm{K}^{+}\right)$-influx (Table 3). By comparison with the dissociation constants of ouabain binding, these data imply a close relationship between occupation of the binding sites by ouabain and inhibition of the sodium pump (Table 3 ).

The experiments described in Fig. 9 have been done under equilibrium conditions for ouabain binding. The close relationship between ouabain binding to its binding sites and inhibition of the sodium pump becomes also evident from the following experiments: simultaneous measurement of dissociation of $\left({ }^{3} \mathrm{H}\right)$-ouabain-bound to heart muscle cells during a preincubation period of $120 \mathrm{~min}$ according to the experiment of Fig. 3-and reactivation of sodium pump activity, determined by $\left.{ }^{86} \mathrm{Rb}^{+}+\mathrm{K}^{+}\right)$-influx. Dissociation of ouabain is strictly paralleled by full reactivation of $\left({ }^{86} \mathrm{Rb}^{+}+\mathrm{K}^{+}\right)$-transport, which was initially depressed by ouabain to $60 \%$ of control level. For both processes - ouabain dissociation and reactivation of ouabain-sensitive $\left({ }^{86} \mathrm{Rb}^{+}+\mathrm{K}^{+}\right)$transport-half times of $1-3 \mathrm{~min}$ at $37^{\circ}$ have been determined (experiments not shown).

The quantitative relationship between receptor occupancy and inhibition of the sodium pump has been obtained by simultaneous measurement of $\left({ }^{3} \mathrm{H}\right)$-ouabain binding, $\left({ }^{86} \mathrm{Rb}^{+}+\mathrm{K}^{+}\right)$-uptake and cell $\mathrm{K}^{+}$at various ouabain concentrations, within the same experiment. This is shown for cardiac muscle cells in the experiment of Fig. 10(a), and for cardiac non muscle cells in the experiment of Fig. 10(b). The data of concentration dependent $\left({ }^{3} \mathrm{H}\right)$-ouabain binding allow calculation of the dissociation constant $K_{\mathrm{D}}$ for ouabain binding as described in the experiment of Fig. 8.

According to the law of mass action, the percentage of binding sites occupied by ouabain can then be calculated (see legend to Fig. 10) and correlated with the rate of ouabain-sensitive $\left({ }^{86} \mathrm{Rb}^{+}+\mathrm{K}^{+}\right)$-uptake and with the amount of ouabain-displaceable cell- $\mathrm{K}^{+}$. The mean values obtained from 9 experiments with cardiac muscle cells and from 5 experiments with cardiac non muscle 

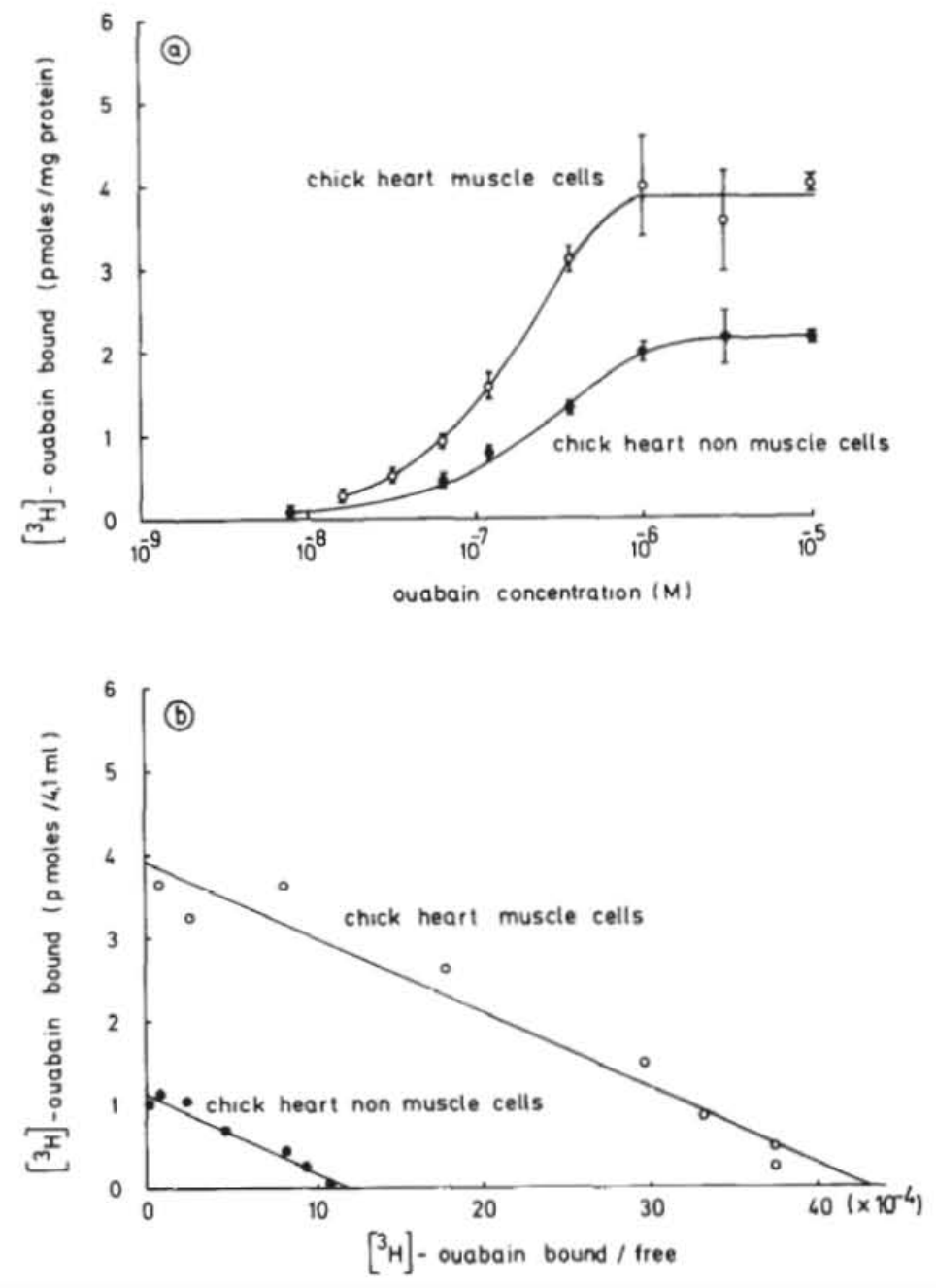

Fig. 8. Concentration dependence of $\left({ }^{3} \mathrm{H}\right)$-ouabain binding to cultured heart cells from chick embryos. (a) Muscle and non muscle cells from hearts of chick embryos have been prepared and cultivated under identical conditions as described in methods. Cells have been incubated for $4 \mathrm{hr}$ in serum-supplemented. Hepes-buffered CMRL-medium $\left(\left[\mathrm{K}^{+}\right]=0.75 \mathrm{mM}\right)$ in the presence of $\left({ }^{3} \mathrm{H}\right)$-ouabain at different concentrations as indicated (see abscissa). Temperature $37^{\circ}$. incubation volume $4.1 \mathrm{ml}$.

Chick heurt muscle cells. $0.91 \mathrm{mg}$ protein/flask; $\left({ }^{3} \mathrm{H}\right.$ )-ouabain $0.9 \times 10^{6} \mathrm{cpm}$ ([ouabain] $=1.6 \times$ $10^{-8} \mathrm{M}$ ), $1.8 \times 10^{6} \mathrm{cpm}$ ([ouabain] $=3.1 \times 10^{-8} \mathrm{M}$ ), $3.7 \times 10^{6} \mathrm{cpm}$ ([ouabain] $\geqq 6.2 \times 10^{-8} \mathrm{M}$ ): for calculation of specific $\left({ }^{3} \mathrm{H}\right)$-ouabain binding, the unspecific binding at $10^{-2} \mathrm{M}$ ouabain (8-9\% of maximal counts bound) has been subtracted from total ( ${ }^{3} \mathrm{H}$ )-ouabain binding.

Chick heart non muscle cells. $0.52 \mathrm{mg}$ protein/flask: $\left({ }^{3} \mathrm{H}\right)$-ouabain $0.4 \times 10^{\circ} \mathrm{cpm}$ ([ouabain] $=$ $7.8 \times 10^{-9} \mathrm{M}$ ), $3.2 \times 10^{6} \mathrm{cpm}$ ([ouabain] $\geqq 6.2 \times 10^{-8} \mathrm{M}$ ); for calculation of specific $\left({ }^{3} \mathrm{H}\right)$-ouabain binding, the unspecific binding at $10^{-2} \mathrm{M}$ ouabain $(7-8 \%$ of maximal counts bound) has been subtracted from total $\left({ }^{3} \mathrm{H}\right)$-ouabain binding. (b) Scatchard Plot analysis [32] of binding curves presented (a). Linear regression analysis yields the following results: chick heart muscle cells $B=4.3$ pmoles/mg protein. $K_{\mathrm{D}}=2.2 \times 10^{-3} \mathrm{M}, r=-0.98$; chick heart non muscle cells $B=2.2$ pmoles $/ \mathrm{mg}$ protein. $K_{\mathrm{D}}=$ $2.3 \times 10^{-7} \mathrm{M}, r=-0.98$.

For preparation and cultivation of cardiac muscle cells, the hearts of 130 chicken embryos (10-dayold) have been used. Cells have been seeded in 45 plastic culture flasks $\left(25 \mathrm{~cm}^{2}\right.$ each) at cell densities of $147,000 / \mathrm{cm}^{2}$. Heart non muscle cells have been obtained from the same preparation, after 1 subcultivation, and have been also seeded in 45 plastic culture flasks $\left(25 \mathrm{~cm}^{2}\right.$ each).

cells - carried out in the same manner as the experiments described in Figs. 10(a) and (b)-are presented in Figs. 10(c) and (d) respectively.

Since complete occupation of the binding sites by ouabain yields complete inhibition of active $\left({ }^{86} \mathrm{Rb}^{+}+\mathrm{K}^{+}\right)$-uptake, binding sites may be classified as cardiac glycoside receptors in cardiac muscle as well as in cardiac non muscle cells. However, a striking dissimilarity exists concerning the quantitative relationship of receptor occupancy and sodium pump inhibition: in non muscle cells, binding of ouabain is strictly coupled to inhibition of active $\left({ }^{86} \mathrm{Rb}^{+}+\mathrm{K}^{+}\right)$-uptake and to lowering of cell- $\mathrm{K}^{+}$; a certain percentage of receptor occupancy yielding 
Table 3. Properties of the cardiac glycoside receptor in cardiac muscle and non muscle cells in culture, prepared from chicken embryos

\begin{tabular}{lcc}
\hline & Heart muscle cells & Heart non muscle cells \\
\hline $\begin{array}{l}\text { Ouabain binding sites }(B) \\
\text { (pmoles/mg protein) }\end{array}$ & $2.6 \pm 0.3$ & $2.1 \pm 0.1$ \\
$\begin{array}{l}\text { Dissociation constant }\left(K_{\mathrm{D}}\right) \\
\text { for ouabain binding }(\mathrm{M})\end{array}$ & $(1.5 \pm 0.2) \times 10^{-7}$ & $(1.9 \pm 0.2) \times 10^{-7}$ \\
$\begin{array}{l}\text { Ouabain-induced inhibition } \\
\text { of }\left({ }^{86} \mathrm{Rb}^{+}+\mathrm{K}^{+}\right) \text {-uptake } \\
\left(\mathrm{EC} \mathrm{S}_{50}, \mathrm{M}\right)\end{array}$ & $(5.8 \pm 0.8) \times 10^{-7}$ & $(2.6 \pm 0.4) \times 10^{-7}$ \\
$\begin{array}{l}\text { Ouabain-induced decrease in } \\
\text { cellular } \mathrm{K}^{+}\left(\mathrm{EC}_{50}, \mathrm{M}\right)\end{array}$ & $(6.7 \pm 0.8) \times 10^{-7}$ & $(2.0 \pm 0.1) \times 10^{-7}$ \\
$\begin{array}{l}\text { Ouabain-induced increase in } \\
\text { cellular } \mathrm{Na}^{+}\left(\mathrm{EC}_{50}, \mathrm{M}\right)\end{array}$ & $(7.4 \pm 1.2) \times 10^{-7}$ & \\
\hline
\end{tabular}

Data have been obtained from experiments as described in Figs. 8 and 9. Values are means \pm S.E.M. $(\mathrm{N}=5-17)$.

the same percentage of pump inhibition and fall in cell- $\mathrm{K}^{+}$. In cardiac muscle cells, on the other hand, up to $40 \%$ of the binding sites can bind ouabain with only minor reduction $(<10 \%)$ of active $\left({ }^{86} \mathrm{Rb}^{+}+\mathrm{K}^{+}\right)$-uptake and cellular $\mathrm{K}^{+}$.

\section{DISCUSSION}

Characterization of binding sites for cardiac gly. cosides in heart cells. Chick heart muscle cells in culture respond well to cardiac glycosides (for review see $[17,33])$ : an increase in pulsation amplitude and contraction velocity is seen at $10^{-7}-10^{-6} \mathrm{M}$ ouabain [6]; drug induced inhibition of the sodium pump is reflected by inhibition of $\left({ }^{86} \mathrm{Rb}^{+}\right)$-uptake with a concomitant increase in intracellular sodium concentration and decrease in intracellular potassium concentration ([2,5,6] see also Fig. 9). In contrast to the qualitative and quantitative well defined actions of cardiac glycosides, data concerning the properties of the cardiac glycoside receptor of these cells are sparse and limited to determination of the number of receptors and their affinity for the ligands [2, 40].

Our results clearly demonstrate that specific binding of $\left({ }^{3} \mathrm{H}\right)$-ouabain to chick heart muscle cells is due to temperature-dependent (Fig. 7) binding of the molecule to a single class of binding sites with high affinity for its ligand (Fig. 8, Table 3), which is destroyed by heat denaturation of the cells (Table 1 ). The observed decrease in the affinity of the receptor by potassium ions results from the depression of the association velocity by this cation (Fig. 6).

Several approaches have been used in our experiments, to characterize $\left({ }^{3} \mathrm{H}\right)$-ouabain binding to cultured chicken heart cells as binding to a single class of ouabain binding sites:

(a) Comparison of kinetic and equilibrium parameters of ouabain binding to intact chicken heart cells:

The dissociation constant $K_{\mathrm{D}}$ for ouabain binding to intact chicken heart cells has been determined from kinetic data of ouabain binding $\left[K_{\mathrm{D}}=\left(k_{-1}\right)\right]$ $\left(k_{+1}\right)$, see text to Fig. 5], as well as by measurement of concentration dependent ouabain binding under equilibrium conditions (see text to Fig, 8). The good agreement of the values obtained by these independent methods $\left(K_{\mathrm{D}}=1.9 \times 10^{-7} \mathrm{M}\right.$ and $1.5 \times 10^{-7}$ $\mathrm{M}$ for heart muscle cells; $K_{\mathrm{D}}=1.3 \times 10^{-7} \mathrm{M}$ and $1.9 \times 10^{-7} \mathrm{M}$ for heart non muscle cells respectively; see Tables 2 and 3 ) characterizes specific binding of ouabain to intact chicken heart cells as binding of all ouabain to a single class of ouabain binding sites.

(b) Comparison of ouabain binding in cultured heart cells and $\left(\mathrm{Na}^{+}+\mathrm{K}^{+}\right)$-ATPase enriched cardiac cell membranes from chick embryos:

For direct comparison of ouabain binding in intact heart cells and cardiac cell membranes, hearts from chicken embryos have been used not only for preparation of heart cells in culture, but also for preparation of $\left(\mathrm{Na}^{+}+\mathrm{K}^{+}\right)$-ATPase enriched cell membranes. In these membranes, a single class of ouabain binding sites could be demonstrated, using the well-established criteria for specific ouabain binding [11]: binding of ouabain to these binding sites is characterized by the following parameters: dissociation constant $K_{\mathrm{D}}=4.3 \times 10^{-7} \mathrm{M}$, association rate constant $k_{+1}=2.0 \times 10^{4} \mathrm{M}^{-1} \mathrm{~s}^{-1}$, dissociation rate constant $k_{-1}=1.1 \times 10^{-2} \mathrm{~s}^{-1}, \mathrm{~K}^{+}$-dependence of association to, but not of dissociation from these binding sites (Figs. 1 and 2). In cultured chicken heart cells, also a single class of ouabain binding sites could be demonstrated, with nearly identical values for these binding parameters: $K_{\mathrm{D}}=(1.3-$ 1.9) $\times 10^{-7} \mathrm{M}, k_{+1}=(2.2-3.2) \times 10^{4} \mathrm{M}^{-1} \mathrm{~s}^{-1}, k_{-1}=$ $(2.8-4.5) \times 10^{-3} \mathrm{~s}^{-1}, \mathrm{~K}^{+}$-dependence of association to, but not of dissociation of ouabain from the binding sites (Tables 2 and 3, Figs. 5, 6 and 8). The good agreement of binding parameters for ouabain in cardiac cell membranes and cultured heart cells—both obtained from hearts of chicken embryos-provides strong experimental evidence that the binding sites for $\left({ }^{3} \mathrm{H}\right)$-ouabain in intact heart cells from chicken embryos are identical with the binding sites for $\left({ }^{3} \mathrm{H}\right)$-ouabain in $\left(\mathrm{Na}^{+}+\mathrm{K}^{+}\right)$-ATPase-enriched cardiac cell membranes.

(c) Correlation of ouabain binding and inhibition of the sodium pump in chicken heart cells in culture:

In heart muscle cells from chicken embryos, specific binding of ouabain is correlated in a quantitative manner to inhibition of the sodium pump (Fig. 10), 


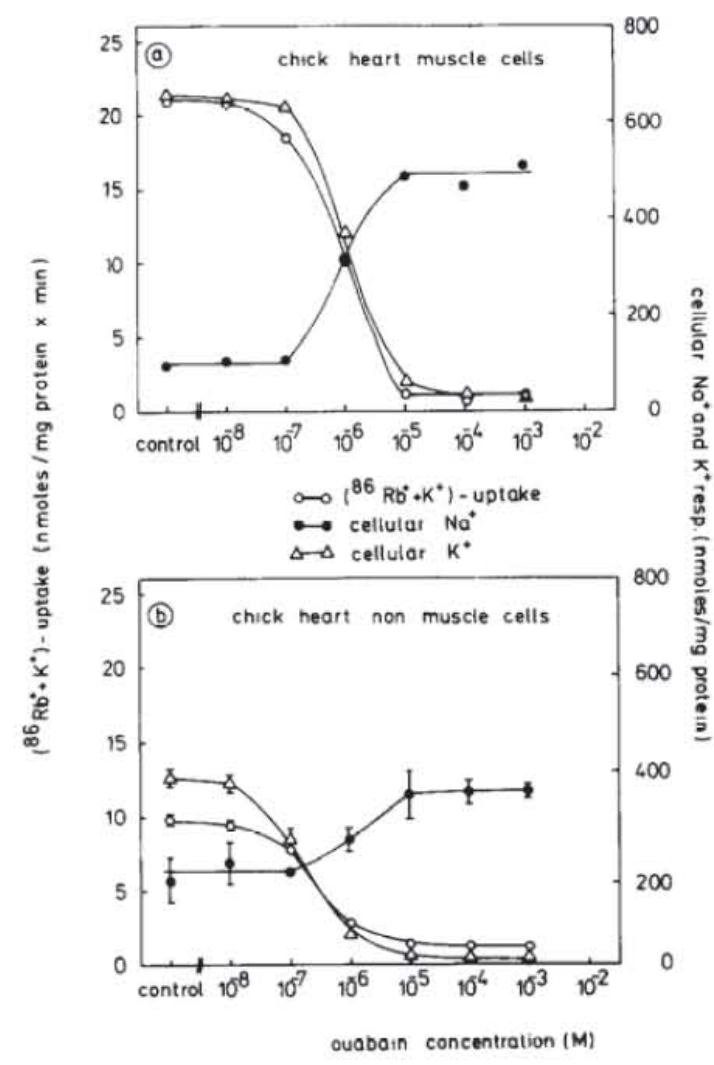

Fig. 9. Influence of ouabain on sodium pump activity in cultured heart cells from chicken embryos. Muscle and non muscle cells from hearts of chick embryos have been prepared and cultivated under identical conditions as described in methods. Cellular $\mathrm{K}^{+}$has been determined by flame photometry, cellular $\mathrm{Na}^{+}$by measurement of ${ }^{22} \mathrm{Na}^{+}$under equilibrium conditions and potassium uptake rates by using ${ }^{86} \mathrm{Rb}^{+}$as radioactive tracer. Prior to measurements, cells have been incubated for $4 \mathrm{hr}$ with different concentrations of ouabain as indicated. $\left[\mathrm{K}^{+}\right]=0.75 \mathrm{mM}$, temp. $37^{\circ}$. Radioactivity and cell protein per flask: (a) $1.91 \times 10^{6} \mathrm{cpm}^{86} \mathrm{Rb}^{+}$ $7.61 \times 10^{6} \mathrm{cpm}^{22} \mathrm{Na}^{+} ; 0.65 \mathrm{mg}$; (b) $1.51 \times 10^{6} \mathrm{cpm}{ }^{86} \mathrm{Rb}^{+}$ $14.25 \times 10^{6} \mathrm{cpm}{ }^{22} \mathrm{Na}^{+}$; $0.30 \mathrm{mg}$; Values are given as mean \pm S.E.M. $\quad(N=4-16)$ for cellular $\mathrm{K}^{+}$; for $\left({ }^{86} \mathrm{Rb}^{+}+\mathrm{K}^{+}\right)$-uptake and cellular $\mathrm{Na}^{+}$, values are given as mean from closely correlating duplicates in (a), and as mean \pm S.D. $(N=3)$ in (b). For further experimental detail see Materials and Methods. For preparation and cultivation of cardiac muscle cells, the hearts of 120 chicken embryos (10-day-old) have been used. Cells have been seeded in 44 plastic culture flasks $\left(25 \mathrm{~cm}^{2}\right.$ each) at cell densities of $90,000 / \mathrm{cm}^{2}$. Heart non muscle cells have been obtained from the same preparation, after 1 subcultivation, and have been also seeded in 44 plastic culture flasks $\left(25 \mathrm{~cm}^{2}\right.$ each).

the quantitative relationship being identical as in cardiac cell membranes for specific ouabain binding and inhibition of $\left(\mathrm{Na}^{+}+\mathrm{K}^{+}\right)$-ATPase (Fig. 1). In heart non muscle cells from chicken embryos, specific binding of ouabain is coupled to sodium pump inhibition even in a strictly stoichiometric manner (Fig. 10). These results rule out the possibility that part of specifically cell-fixed ouabain in these cells also represents internalized, functionally inactive ouabain.
Dissociation of all specifically bound ouabain in these heart cells can be described by a single first order rate constant (Fig. 5). This process, on the other hand, concomitantly reactivates the sodium pump; the time constants for ouabain dissociation. reactivation of ouabain-inhibited $\left({ }^{86} \mathrm{Rb}^{+}+\mathrm{K}^{+}\right)$influx and normalization of ouabain-depressed cell$\mathrm{K}^{+}$being within the same range (see results). These data, therefore, add further strong evidence that specific binding of ouabain to heart cells from chicken embryos represents only binding to specific binding sites being linked to the $\left(\mathrm{Na}^{+}+\mathrm{K}^{+}\right)$-ATPase molecule.

(d) Lack of experimental evidence that a considerable part of specific ouabain binding in cultured heart cells represents internalization of ouabain:

Intact cells are able to internalize ouabain, initially bound to its specific, cell membrane located binding sites. This process has been thoroughly studied in cultured tumor cells (HeLa cells) by various groups $[9,21,29]$

Concerning characteristic features of ouabain internalization in $\mathrm{HeLa}$ cells, $\left({ }^{3} \mathrm{H}\right)$-ouabain binding to these cells can be described as follows: (a) biphasic uptake kinetics and absence of saturation for $\left({ }^{3} \mathrm{H}\right)$ ouabain binding up to $50 \mathrm{hr}$ of incubation [9]; (b) very slow release of cell-fixed $\left({ }^{3} \mathrm{H}\right)$-ouabain with a half time of $20-70 \mathrm{hr}[9,21]$, while dissociation of $\left({ }^{3} \mathrm{H}\right)$-ouabain from $\left(\mathrm{Na}^{+}+\mathrm{K}^{+}\right)$-ATPase enriched cell membranes occurs at a much faster rate; (c) after blocking of the sodium pump sites with unlabelled ouabain for $10 \mathrm{~min}$. followed by subsequent incubation of the cells in ouabain free medium. $\mathrm{K}^{+}$-influx recovers completely within $3 \mathrm{hr}$, while recovery of $\left({ }^{3} \mathrm{H}\right)$-ouabain binding takes some $24 \mathrm{hr}$ to occur [21].

In cultured heart cells from chicken embryos, however, none of these findings-being representative of ouabain internalization-has been found in our experiments: (a) binding of $\left({ }^{3} \mathrm{H}\right)$-ouabain can be described by second order kinetics, in agreement with binding to a single class of binding sites; saturation of specific $\left({ }^{3} \mathrm{H}\right)$-ouabain binding is reached within $30 \mathrm{~min}$, remaining constant for at least $8 \mathrm{hr}$ (Figs. 3 and 5, text to Fig. 3); (b) dissociation of specifically bound $\left({ }^{3} \mathrm{H}\right)$-ouabain from cultured heart cells occurs rapidly $\left(T_{1 / 2} \sim 2.5 \mathrm{~min}\right)$, with about the same dissociation rate constant as that found for $\left(\mathrm{Na}^{+}+\mathrm{K}^{+}\right)$-ATPase enriched cell membranes (see section b); (c) specific binding of ouabain is coupled to inhibition of the sodium pump (see section $c$ ), the stoichiometry of coupling being very similar with cardiac cell membranes (Fig. 1) and heart muscle cells in culture (Fig. 10); (d) in cultured heart muscle cells, bound unlabelled ouabain can be replaced by $\left({ }^{3} \mathrm{H}\right)$-ouabain by more than $90 \%$, after washout of unlabelled ouabain for $60 \mathrm{~min}$ (see text to Fig. 3)

Therefore, in cultured heart cells from chicken embryos, no experimental evidence exists that considerable part of specifically bound $\left({ }^{3} \mathrm{H}\right)$-ouabain represents-under our experimental conditionsinternalized $\left({ }^{3} \mathrm{H}\right)$-ouabain. We may, however, not exclude that part of unspecific $\left({ }^{3} \mathrm{H}\right)$-ouabain binding (for definition see text to Fig. 3) represents internalization of ouabain. This, however, would not falsify our data concerning characterization of 

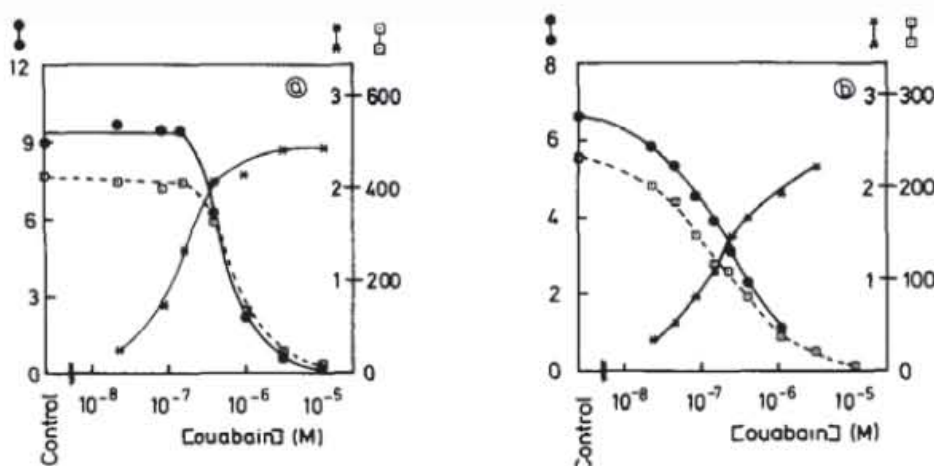

* * specific $\left({ }^{3} \mathrm{H}\right)$-ouabain binding (pmoles/mg protein)

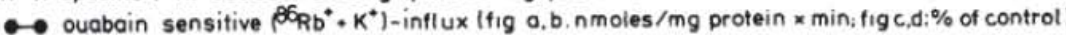

$0-0$ ouabain sensitive cell $\mathrm{K}^{*}$

(fig a, b: nmoles/mg protein, fig c,d: \% of control)
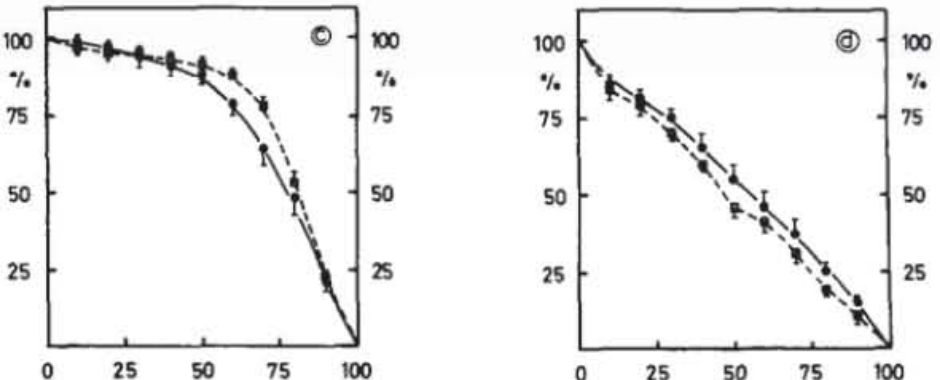

binding site-ligand-complexes $(\%)$

Fig. 10. Effect of $\left({ }^{3} \mathrm{H}\right)$-ouabain binding to its receptor on ouabain-sensitive $\left({ }^{86} \mathrm{Rb}^{+}+\mathrm{K}^{+}\right)$-influx rate and cellular $\mathrm{K}^{+}$pool in cultured muscle cells (a and c) and non muscle cells (b and d) from chicken embryos. In (a) and (b), $\left.{ }^{3} \mathrm{H}\right)$-ouabain binding has been measured and analysed according to Scatchard [32]-as described in the experiment of Fig. 8-and $\left({ }^{86} \mathrm{Rb}^{+}+\mathrm{K}^{+}\right)$-uptake as well as cellular $\mathrm{K}^{+}$has been determined-as shown in the experiment of Fig. 9-at various ouabain concentrations; $\left[\mathrm{K}^{+}\right]=$ $0.75 \mathrm{mM}$; temperature $37^{\circ}$. For preparation and cultivation of heart muscle cells, the hearts of 190 chicken embryos (10-day-old) have been used; cells have been seeded in 51 plastic culture flasks $\left(25 \mathrm{~cm}^{2}\right.$ each) at cell density of $80,000 / \mathrm{cm}^{2} .2 .45 \times 10^{6} \mathrm{cpm}^{86} \mathrm{Rb}^{+}$and $(0.96-3.83) \times 10^{6} \mathrm{cpm}\left({ }^{3} \mathrm{H}\right)$-ouabain per flask respectively; $1.16 \mathrm{mg}$ protein/flask. Scatchard plot analysis of $\left({ }^{3} \mathrm{H}\right)$-ouabain binding: $K_{\mathrm{D}}=$ $2.0 \times 10^{-7} \mathrm{M} ; B=2.7 \mathrm{pmoles} / \mathrm{mg}$ protein. Values are given as mean from $N=2\left[\left({ }^{86} \mathrm{Rb}{ }^{\prime}+\mathrm{K}^{\prime}\right)\right.$-uptake $]$, $N=3\left[\left({ }^{3} \mathrm{H}\right)\right.$-ouabain binding $], N=5\left(\right.$ cell $\left.-\mathrm{K}^{+}\right)$. For calculation of specific $\left({ }^{3} \mathrm{H}\right)$-ouabain binding, the unspecific binding at $10^{-2} \mathrm{M}$ ouabain has been subtracted from total $\left({ }^{3} \mathrm{H}\right)$-ouabain binding. For calculation of ouabain-displaceable cell- $\mathrm{K}^{+}$and ouabain-sensitive $\left({ }^{8}{ }^{-6} \mathrm{Bb}^{+}+\mathrm{K}^{+}\right)$-influx, cell- $\mathrm{K}^{+}$at $10^{-2} \mathrm{M}$ ouabain $\left(10 \mathrm{nmoles} / \mathrm{mg}\right.$ protein) and $\left({ }^{86} \mathrm{Rb}^{+}+\mathrm{K}^{+}\right)$-influx at $10^{-2} \mathrm{M}$ ouabain $(0.35 \mathrm{nmoles} / \mathrm{mg}$ protein $\times$ min $)$ have been subtracted from total cell- $\mathrm{K}^{+}$and total $\left({ }^{86} \mathrm{Rb}^{+}+\mathrm{K}^{+}\right)$-uptake, respectively, at the ouabain concentration chosen. (b) Non muscle cells obtained from the hearts of 200 chicken embryos (11day-oid) have been subcultivated and seeded in 60 plastic culture flasks $\left(25 \mathrm{~cm}^{2}\right.$ each). $1.38 \times 10^{6} \mathrm{cpm}$ $\left({ }^{86} \mathrm{Rb}^{+}\right)$and $(0.96-3.83) \times 10^{6} \mathrm{cpm}\left({ }^{3} \mathrm{H}\right)$-ouabain respectively; $0.25 \mathrm{mg}$ protein/flask. Scatchard plot analysis of $\left({ }^{3} \mathrm{H}\right)$-ouabain binding: $K_{\mathrm{D}}=1.4 \times 10^{-7} \mathrm{M} ; B=2.3$ pmoles $/ \mathrm{mg}$ protein. Values are given as mean from $N=3\left({ }^{86} \mathrm{Rb}^{+}+\mathrm{K}^{+}\right)$-uptake, $\left({ }^{3} \mathrm{H}\right)$-ouabain binding) and $N=6$ (cell- $\left.\mathrm{K}^{+}\right)$. For calculation of specific $\left({ }^{3} \mathrm{H}\right)$-ouabain binding, the unspecific binding at $10^{-2} \mathrm{M}$ ouabain has been subtracted from total $\left.{ }^{3} \mathrm{H}\right)$-ouabain binding. For calculation of ouabain displaceable cell $\mathrm{K}^{+}$and ouabain-sensitive $\left({ }^{86} \mathrm{Rb}^{+}+\mathrm{K}^{+}\right)$-influx, cell $\mathrm{K}^{+}$at $10^{-2} \mathrm{M}$ ouabain $\left(10 \mathrm{nmoles} / \mathrm{mg}\right.$ protein) and $\left({ }^{8 \times} \mathrm{Rb}^{-}+\mathrm{K}^{-}\right)$influx at $10^{-2} \mathrm{M}$ ouabain $(1.21$ nmoles $/ \mathrm{mg}$ protein $\times \min )$ have been subtracted from total cell $\mathrm{K}^{-}$and total $\left({ }^{86} \mathrm{Rb}^{+}+\mathrm{K}^{+}\right)$uptake respectively, at the ouabain concentration chosen. (c) and (d) According to $K_{\mathrm{D}}=([\mathrm{O}] \times[\mathrm{B}]) /[\mathrm{BO}]$, the percentage of ouabain binding sites occupied by ouabain $([\mathrm{BO}])$ can be calculated for every ouabain concentration $([\mathrm{O}])$ chosen; $[\mathrm{B}]=$ concentration of free ouabain binding sites $=$ concentration of total binding sites $-[\mathrm{BO}]$. The calculation is based on the assumption that one ouabain binding site binds one molecule of ouabain. From concentration effect curves, the values for ouabain-sensitive $\left({ }^{86} \mathrm{Rb}^{+}+\mathrm{K}^{+}\right.$)-influx and for cell $\mathrm{K}^{+}$(in $\%$ of control without ouabain) have been obtained for the ouabain concentrations producing $10,20,30 \ldots 90 \%$ of binding site-ligand-complexes. These relationships have been obtained for heart muscle cells (based on data from 9 experiments according to $\mathrm{a}$; $\mathrm{M} \pm \mathrm{S}$.E.M.; (c), as well as for heart non muscle cells (5 experiments according to b: $M \pm$ S.E.M.: d) 
$\left(\mathrm{Na}^{+}+\mathrm{K}^{+}\right)$-ATPase linked ouabain binding sites in cultured chicken heart cells.

The lack of considerable internalization rates for ouabain seems not very surprising in view of experimental findings presented by Lamb and Ogden [20], suggesting that internalization may vary with the growth state of the cells. Differentiated cells, e.g. heart muscle cells in culture, may therefore have very different internalization rates than cells growing rapidly in culture (e.g. tumor cells).

In summary, all experimental evidence supports the assumption that specific $\left({ }^{3} \mathrm{H}\right)$-ouabain binding in cultured heart cells from chicken embryos represents binding to a single class of $\left(\mathrm{Na}^{+}+\mathrm{K}^{+}\right)$-ATPase linked ouabain binding sites. The experimental findings argue against the assumption that considerable part of specific $\left({ }^{3} \mathrm{H}\right)$-ouabain binding represents internalization of ouabain.

When working with cardiac membranes, one has to be aware that the heart consists of muscle as well as non muscle cells (1). As an advantage of cell culture technique, both cell types can be cultivated separately (see methods), and ouabain binding to muscle cells can therefore be differentiated from binding to non muscle cells. A comparison of ouabain binding sites in both cell types is given in Tables 2 and 3 , demonstrating similar binding site-ligand interactions with respect to association, dissociation and temperature dependence.

Quantification of the number of binding sites for cardiac glycosides in heart cells in culture. The number of cardiac glycoside binding sites has been determined in a variety of mammalian cells $[4,8,9,13]$ $10^{4}-10^{6}$ binding sites/cell normally have been found; the binding site density of erythrocytes ( 200 binding sites/cell) being the exception.

Concerning heart cells in culture, data are available for several cell types (binding sites/cell): heart muscle cells from neonatal rats $1.6 \times 10^{6}[24]$ and 147,000 [14]; heart non muscle cells from neonatal rats 33,000 [14]; heart muscle cells from chick embryos 540,000 [2]. In isolated heart myocytes from adult dogs, 740,000 binding sites/cell have been determined [28], in rabbit cardiocytes $8.5 \times 10^{6}[10]$.

In our measurements of ouabain binding sites in chick heart cells, we used cell protein as reference [40]. Heart muscle cells had about $25 \%$ more ouabain binding sites/mg protein than heart non muscle cells (Table 3). Taking into account the different protein/cell ratio for both cell types, we have calculated about 860,000 binding sites/cell for muscle cells, and about 300,000 sites/cell for non muscle cells [40]. However, regarding these data, one should be aware of the large differences in protein/cell ratios reported in literature, ranging from $(0.7$ to $15.5) \times 10^{6}$ heart muscle cells and $(0.8$ to 41.6$) \times 10^{6}$ heart non muscle cells per mg of protein. These values have been calculated according to data from several authors $[14,22,26,28,30,35,40]$.

Cardiac glycoside receptors in cultured heart cells. Specific binding of a drug to cellular binding sites only then constitutes the first step of a receptor function, when binding of the drug is followed by a biological effect. In case of cardiac glycosides, receptor-mediated biological effects in the intact myocardial muscle cell are an increase in force of contraction, as well as an inhibition of the sodium pump. Can one or both of these effects be correlated with ouabain binding to chicken heart cells in culture?

The positive inotropic effect of cardiac glycosides produced in these cells has been studied by Biedert et al. [6]: it occurs within the concentration range of $10^{-7}-10^{-6} \mathrm{M}$, is demonstrable within $1-2 \mathrm{~min}$ after drug addition, and is reversed within 6-7 min after washout of ouabain. Therefore, ouabain-induced positive inotropy correlates well with ouabain binding, as can be seen from the dissociation constant $\left(K_{\mathrm{D}}=1.5 \times 10^{-7} \mathrm{M}\right.$, Table 3$)$, and half-time for dissociation $\left(T_{1 / 2}=2.5 \mathrm{~min}\right.$, calculated from $k_{-1}=$ $4.5 \times 10^{-3} \mathrm{~s}^{-1}$, Table 2) for ouabain binding. The latter comparison is justified despite different experimental conditions (especially concerning $\mathrm{K}^{+}$concentration in incubation medium), because dissociation of ouabain from its binding site is nearly independent from $\mathrm{K}^{+}$ions (Fig. 6).

The receptor properties of ouabain binding sites are also obvious from comparison of the concentration dependence of ouabain binding and inhibition of the sodium pump (Table 3 ). Though the extent of coupling of ouabain binding and sodium pump inhibition is different in cardiac muscle and non muscle cells (see next paragraph), a clear cut dependence of pump inhibition on occupation of ouabain binding sites exists in both cell types (Fig. 10, [40]).

In view of this experimental evidence we may conclude that the characterized class of ouabain bindings sites in cardiac muscle and non muscle cells from chick embryos is identical with the cardiac glycoside receptor of these cells. From the data of Table 3, the receptor density-assumed to be identical with the density of sodium pump moleculescan be estimated as $430 / \mu \mathrm{m}^{2}$ (heart muscle cells) and $300 / \mu \mathrm{m}^{2}$ (heart non muscle cells) cell surface; the turnover rate of the sodium pump in these cellsunder the experimental conditions described-being about $50 / \mathrm{s}$ (muscle cells) and $30 / \mathrm{s}$ (non muscle cells) respectively (for further details of calculation see Materials and Methods).

Ouabain binding sites have also been described in cultured heart muscle cells from neonatal rats $[14,24,39]$. Identification of these binding sites as cardiac glycoside receptors, however, is complicated for two reasons: (a) experimental evidence for two classes of ouabain binding sites (b) lack of close correlation of ouabain binding to the high affinity binding site $\left(K_{\mathrm{D}} \sim 10^{-8} \mathrm{M}\right)$ and ouabain-induced inhibition of the sodium pump $\left(\mathrm{EC}_{5_{0}} \sim 10^{-5} \mathrm{M}\right)$.

Consequences of ouabain binding on sodium pump activity in cardiac muscle and non muscle cells from chicken embryos. A substantial difference exists in cardiac muscle and non muscle cells concerning coupling of ouabain binding to its receptor and inhibition of the sodium pump: in cardiac non muscle cells from chicken embryos, cardiac glycoside receptor occupancy is strictly coupled to sodium pump inhibition, the extent of inhibition of active $\mathrm{Na}^{+} / \mathrm{K}^{+}$-transport being stoichiometrically linked to receptor occupancy (Fig. 10). Therefore, the same result has been found in cardiac non muscle cells as described for human erythrocytes [15]. In cardiac muscle cells, on the other hand, up to $40 \%$ of cardiac 
glycoside receptors can bind ouabain without stoichiometric inhibition of active $\left({ }^{86} \mathrm{Rb}^{+}+\mathrm{K}^{+}\right)$-uptake (Fig. 10). Therefore, the coupling ratio of cardiac glycoside receptor occupancy and inhibition of active $\mathrm{Na}^{+}, \mathrm{K}^{+}$-transport can be different in different cell types, even of the same organ and animal species.

All attempts to explain this different behaviour of cardiac muscle and non muscle cells remain-at present-speculative. Different densities of sodium pump molecules in the cell membrane (see preceding chapter) or different responses of non-inhibited pump molecules to intracellular sodium accumulation in the presence of partial sodium pump inhibition $[3,41]$ could be responsible for it. The lack of strict coupling of receptor occupancy and sodium pump inhibition in cardiac muscle cells may also be explained by ouabain binding to functionally inactive or latent sodium pump molecules, by the co-existence of cardiac glycoside receptors yielding either stimulation or inhibition of the sodium pump [16], by cooperativity effects between sodium pump molecules, or by binding of ouabain to additional binding sites, not being linked to inactivation of $\left(\mathrm{Na}^{+}+\mathrm{K}^{+}\right)$-ATPase. Discussing these possibilities, however, it should be kept in mind that only one single class of ouabain binding sites has been identified in our experiments (Fig. 8), whose binding properties show no substantial difference in cardiac muscle and non muscle cells (Table 2). Furthermore, it has to be taken into account that strict coupling of ouabain binding and $\left(\mathrm{Na}^{+}+\mathrm{K}^{+}\right)$-ATPase inhibition is not only absent in intact cardiac muscle cells, but also in cardiac cell membranes (Fig. 1, [36]), mainly consisting of $\left(\mathrm{Na}^{+}+\mathrm{K}^{+}\right)$-ATPase activity from cardiac muscle cells.

What are the consequences of the non-stoichiometric correlation of ouabain binding and inhibition of active $\mathrm{Na}^{+}, \mathrm{K}^{+}$-transport in cardiac muscle cells?

Positive inotropy of cardiac glycosides is correlated with some $20-30 \%$ of occupancy of cardiac glycoside receptors in the heart [13]. Within this range, changes in $\mathrm{Na}^{+}$- and $\mathrm{K}^{+}$-contents in the heart should be small or even absent (Fig. 10), which is in agreement with experimental findings presented in the literature (for review see [25]). Furthermore, active $\mathrm{Na}^{+}, \mathrm{K}^{+}$-transport is inhibited only to a small extent in the therapeutic range of receptor occupancy, which may be difficult to detect in the intact heart or in heart muscle preparations (see Introduction). This could explain part of the contradictory results reported in the literature concerning the demonstration of sodium pump inhibition in the presence of therapeutic levels of cardiac glycosides [18, 31].

Further attempts will be made to establish the correlation of receptor occupancy and sodium pump inhibition in the presence of physiological $\mathrm{K}^{+}$concentrations, to study the effect of beating frequency on coupling and to correlate the positive inotropic effect of cardiac glycosides with receptor occupancy and sodium pump inhibition in these cells. By doing this, the still open question of the role of sodium pump inhibition in positive inotropic action of cardiac glycosides [27] may be further clarified.

Acknowledgements-This work was supported by the Wilhelm Sander-Stiftung (78.014.2) and by Deutsche For- schungsgemeinschaft (Er 65/4-3). The excellent technical assistance of B. Walther is gratefully acknowledged.

\section{REFERENCES}

1. C. P. Adler, W. P. Ringlage and N. Böhm, Path. Res. Pract. 172, 25 (1981).

2. J. F. Aiton, J. F. Lamb and P. Ogden, Br. J. Pharmac. 73, 333 (1981).

3. T. Akera, Science 198, 569 (1977).

4. P. F. Baker and J. S. Willis, Biochim. biophys. Acta 183, 646 (1969).

5. W. H. Barry, S. Biedert, D. S. Miura and T. W. Smith, Circ. Res. 49, 141 (1981).

6. S. Biedert, W. H. Barry and T. W. Smith, J. gen. Physiol. 74, 479 (1979).

7. B. Blondel, I. Roijen and J. P. Cheneval, Experientia 27, 356 (1971)

8. D. Charlemagne, L. Lelievre, P. Jolles and A. Paraf, Biochem. Pharmac. 28, 3513 (1979).

9. J. S. Cook, E. H. Tate and C. Shaffer, J. Cell. Physiol. 110,84 (1982)

10. J. W. Dow, N. G. L. Harding and T. Powell, Cardiovasc. Res. 15, 549 (1981).

11. E. Erdmann and W. Schoner, Biochim. biophys. Acta 307, 386 (1973).

12. E. Erdmann, G. Philipp and H. Scholz, Biochem. Pharmac. 29, 3219 (1980)

13. E. Erdmann, Cardiac glycosides. In Handbook of Experimental Pharmacology (Ed. K. Greeff), Vol. 56/1, p. 337. Springer, Berlin (1981).

14. I. Friedman, H. Schwalb, H. Hallaq, A. Pinson and M. Heller, Biochim. biophys. Acta 598, 272 (1980).

15. J. D. Gardner and D. R. Kino, J. clin. Invest. 52, 1845 (1973).

16. T. Godfraind, Cardiac glycosides. In Handbook of Experimental Pharmacology, Vol. 56/I, p. 381.

17. K. Greeff and D. Hafner, Cardiac glycosides. In Handbook of Experimental Pharmacology, Vol. 56/1, p. 161.

18. T. J. Hougen and T. W. Smith, Circ. Res. 42, 856 (1978).

19. R. Kaufmann, H. Tritthart, S. Rodenroth and B. Rost, Pflügers Arch. 311, 25 (1969).

20. J. F. Lamb and P. Ogden, J. Physiol. 316, 8 (1981).

21. J. F. Lamb and P. Ogden, Q. J. exp. Physiol. 67, 105 (1982).

22. H. Lewis and I. Harary, Archs Biochem. Biophys. 142, 501 (1971)

23. W. J. Marvin, R. B. Robinson and K. Hermsmeyer, Circ. Res. 45, 528 (1979)

24. D. McCall, Am. J. Physiol. 236, C87 (1979).

25. W. Nayler and E. A. Noack, Cardiac glycosides. In Handbook of Experimental Pharmacology, Vol. 56/I p. 407.

26. S. Nees, A. L. Gerbes and E. Gerlach, Eur. J. Cell Biol. 24, 287 (1981).

27. D. Noble, Cardiovasc. Res. 14, 495 (1980).

28. T. Onji and M.-S. Liu, Archs Biochem. Biophys. 207, 148 (1981).

29. L. R. Pollack, E. H. Tate and I. S. Cook, Am. J. Physiol. 241, C173 (1981).

30. H. Porzig, C. Becker and H. Reuter, Naunyn-Schmiedeberg's Arch. Pharmac. 321, 89 (1982).

31. H. M. Rhee, W.-H. Huang and A. Askari, Eur. J. Pharmac. 70, 273 (1981).

32. G. Scatchard, Ann. N.Y. Acad. Sci. 51, 660 (1949).

33. O. F. Schanne and G. Bkaily, Can. J. Physiol. Pharmac. 59, 443 (1981).

34. W. Schoner, C, von Ilberg, R. Kramer and W. Seubert, Eur. J. Biochem. 1, 334 (1967). 
35. P. Simpson, A. McGrath and S. Savion, Circ. Res. 51. 787 (1982).

36. N. Sperelakis and E. C. Lee, Biochim. biophys. Acta 233, 562 (1971)

37. K. Werdan, G. Bauriedel, M. Bozsik, W. Krawietz and E. Erdmann, Biochim. biophys. Acta 597, 364 (1980).

38. K. Werdan, G. Bauriedel, B. Fischer, W. Krawietz,
E. Erdmann, W. Schmitz and H. Scholz, Biochim. biophys. Acta 687, 79 (1982).

39. K. Werdan, B. Zwißler, B. Wagenknecht. W. Krawietz and E. Erdmann, Eur. J. Cell Biol. 27, 33 (1982).

40. K. Werdan, B. Zwißler, B. Wagenknecht, W. Krawietz and E. Erdmann, Biochem. Pharmac. 32, 757 (1983).

41. S. Yamamoto, T. Akera and T. Brody, Biochim. biophys. Acta 555, 270 (1979). 